\title{
Paclitaxel Impedes EGFR-mutated PC9 Cell Growth via Reactive Oxygen Species-mediated DNA Damage and EGFR/PI3K/AKT/mTOR Signaling Pathway Suppression
}

\author{
MD MOHIUDDIN and KAZUO KASAHARA
}

\author{
Department of Respiratory Medicine, Kanazawa University, Ishikawa, Japan
}

\begin{abstract}
Background/Aim: Paclitaxel is used as a first-line and subsequent therapy for the treatment of various cancers. However, the function and mechanisms of action of paclitaxel in non-small-cell lung cancer (NSCLC) remain unknown. In this study, the molecular mechanism underlying the anticancer activity of paclitaxel was investigated in vitro in a human NSCLC cell line carrying the EGFR exon 19 deletion (PC9). Materials and Methods: PC9 cells were treated with paclitaxel and then evaluated with a cell viability assay, DAPI staining, Giemsa staining, apoptosis assay, reactive oxygen species (ROS) assay, terminal deoxynucleotidyl transferase dUTP nick-end labeling assay and Western blotting. Results: Paclitaxel markedly decreased the viability of PC9 cells and induced morphological signs of apoptosis. The apoptotic effects of paclitaxel were observed through caspase cascade activation, along with ROS generation and loss of mitochondrial membrane potential (MMP). Furthermore, paclitaxel induced ROS-mediated DNA damage that triggered the activation of the extrinsic pathway of apoptosis via the up-regulation of death receptor (DR5) and caspase- 8 activation. In addition, we found that paclitaxel effectively suppressed the EGFR/PI3K/AKT/mTOR signaling pathway to impede PC9 cell growth. Paclitaxel induced cell cycle arrest at the G1 phase in response to DNA damage, in association with the suppression of CDC25A, Cdk2 and Cyclin E1 protein expression. Conclusion: Paclitaxel showed anticancer effects against NSCLC by
\end{abstract}

This article is freely accessible online.

Correspondence to: Md Mohiuddin, Department of Respiratory Medicine, Graduate School of Medical Sciences, Kanazawa University, 13-1 Takaramachi, Kanazawa, Ishikawa, 920-8641, Japan. Tel: +81 7022501723, e-mail: mohiuddin@med.kanazawau.ac.jp, mohiuddin.pharma_seu@yahoo.com

Key Words: Paclitaxel, non-small-cell lung cancer, ROS, apoptosis, PC9 cell line, EGFR. activating extrinsic and intrinsic apoptotic pathways through enhancing ROS generation, inducing cell cycle arrest, and suppressing EGFR/PI3K/AKT/mTOR signaling pathway.

In the United States, nearly a quarter of all cancer deaths are due to lung cancer (1). Non-small-cell lung cancer (NSCLC) is the most common type and accounts for approximately $85 \%$ of all lung cancer cases in the United States (2). Paclitaxel is an antimicrotubule agent that effectively treats various cancers as first-line chemotherapy $(3,4)$. However, its molecular mechanism of action in NSCLC is still not fully understood.

In cell death regulation, reactive oxygen species (ROS) play a fundamental role (5). It has been reported that elevated ROS production can expedite cancer treatment response (6). As mediators, ROS are well known to cause oxidative DNA damage (7). ATM serine/threonine kinase (ATM)/ATR serine/threonine kinase (ATR) protein kinases and a network of sensory proteins play an essential role in the DNA damage response (8). Activated ATR and ATM phosphorylate the checkpoint kinases Chk1 and Chk2, respectively, and regulate the proteins involved in the DNA damage response (DDR), DNA repair, and cell cycle arrest progression (9). Typically, stable cell cycle arrest occurs in response to DNA damage, called cellular senescence, thereby limiting cell proliferation (10). In addition, increased ROS production is associated with the loss of mitochondrial membrane potential (MMP) (11). In response to DNA damage, Bax/Bak can be activated to induce mitochondrial membrane permeabilization through the inhibition of antiapoptotic molecules, such as Bcl-2 and Bcl-xL (12).

In numerous cancer cells, tumor necrosis factor (TNF)related apoptosis-inducing ligand (TRAIL) enhances apoptosis (13). In the extrinsic apoptosis pathway, TRAIL binds to the death receptors DR4 and DR5 to induce apoptosis by recruiting the death-inducing signaling complex (DISC) (14-16). Through the death domain (DD) and death effector domain (DRD), Fas-associated protein death domain (FADD) corporates with death receptors (DRs) and 
procaspase- 8 (17). The formation of DISC triggers the activation of caspase-8, leading to the activation of downstream effector caspases (e.g. caspase-3, caspase-7) and thereby inducing TRAIL-mediated apoptosis $(17,18)$. In addition, the activation of caspase- 8 cleaves Bid into tBid, which triggers the mitochondrial apoptotic pathway, thus releasing cytochrome c (19). Once cytochrome c is released from the mitochondria into the cytoplasm, it can initiate the caspase cascade's activation by interacting with apoptotic protease-activating factors (Apafs) (20).

Epidermal growth factor receptor (EGFR) is a transmembrane protein and receptor for members of the epidermal growth factor (EGF) family of extracellular protein ligands (21). Binding of the ligand to the extracellular domain results in EGFR activation. Activated EGFR then homodimerizes, leading to intracellular tyrosine kinase phosphorylation and triggering the $\mathrm{PI} 3 \mathrm{~K} / \mathrm{Akt} / \mathrm{mTOR}$ intracellular signaling pathway (22). EGFR plays a crucial role in repairing DNA damage (23). However, the anticancer effects and mechanisms of action of paclitaxel in human EGFR-mutated PC9 cells remain unclear. Therefore, the major purpose of the present study was to evaluate the impact of paclitaxel on growth inhibition in EGFR-mutated PC9 cells and clarify the underlying mechanisms.

\section{Materials and Methods}

Cell line and cell culture. Professor K. Hayata (Tokyo Medical College, Tokyo, Japan) provided the PC9 (EGFR exon 19 deletion) human NSCLC cell line derived from a previously untreated adenocarcinoma patient (24). PC9 cells were cultured in RPMI 1640 medium (Invitrogen, Grand Island, NY, USA) containing 10\% fetal bovine serum (FBS; Invitrogen) and maintained at $37^{\circ} \mathrm{C}$ in a humidified atmosphere containing $5 \% \mathrm{CO}_{2}$.

Drug preparation. Paclitaxel $\left[\mathrm{C}_{47} \mathrm{H}_{51} \mathrm{NO}_{14}\right]$ was obtained from FUJIFILM Wako Pure Chemical Corporation (Osaka, Japan). This drug was dissolved in DMSO for in vitro experiments.

Cell proliferation assay. The water-soluble tetrazolium salt (WST1) assay (Cell Proliferation Reagent WST-1; Roche, Tokyo, Japan) was used to evaluate the cytotoxicity of different paclitaxel concentrations (50 and $100 \mathrm{nM}$ ). A 100- $\mu \mathrm{l}$ volume of a growing cell suspension was seeded into each well $\left(4 \times 10^{3}\right.$ cells/well $)$ of a $96-$ well microtiter plate, and $100 \mu \mathrm{l}$ of a solution of paclitaxel at different concentrations was added to each well. After incubation for $72 \mathrm{~h}$ at $37^{\circ} \mathrm{C}$ in a $5 \%$ carbon dioxide atmosphere, $10 \mu \mathrm{l}$ of WST1 solution was added to each well, and the plates were incubated at $37^{\circ} \mathrm{C}$ for a further $4 \mathrm{~h}$. Sample absorbance was measured at $450 \mathrm{~nm}$ using a microplate enzyme-linked immunosorbent assay reader (Multiskan FC; Thermo Scientific, Tokyo, Japan).

Giemsa and DAPI staining. For $72 \mathrm{~h}$, PC9 cells were treated in 12well plates with 2 concentrations of paclitaxel (50 and $100 \mathrm{nM}$ ) or with $0.1 \%$ DMSO as a control. DAPI (Invitrogen) was used to stain cells fixed in $4 \%$ paraformaldehyde in phosphate-buffered solution (FUJIFILM Wako Pure Chemical Corporation) and permeabilized with $0.1 \%$ Triton X-100 (Sigma-Aldrich, Tokyo, Japan). The morphology of cell nuclei was observed using a BZ-X710 All-in-
One Fluorescence Microscope (Keyence, Osaka, Japan). Giemsa staining (Merck KGaA, Darmstadt, Germany) was performed with methanol-fixed cells, and morphological changes were evaluated under a light microscope.

ROS assay. To measure the ROS in cells by flow cytometry, we used an ab186029 (Abcam, Tokyo, Japan) Cellular Reactive Oxygen Species Detection Assay Kit (Deep Red Fluorescence), as described previously (25). In brief, after $72 \mathrm{~h}$ of drug treatment, cells were collected to stain with ROS deep red dye working solution. Subsequently, cells were incubated at $37^{\circ} \mathrm{C}$ for $60 \mathrm{~min}$ before being subjected to a flow cytometry analysis. The signal was calculated in terms of the median fluorescence intensity (MFI).

Terminal deoxynucleotidyl transferase dUTP nick-end labeling (TUNEL) assay. For $72 \mathrm{~h}$, PC9 cells were treated with different concentrations of paclitaxel (50 and $100 \mathrm{nM}$ ) or with $0.1 \%$ DMSO as a control. We used the in situ Direct DNA Fragmentation (TUNEL) Assay Kit (ab66108; Abcam) to measure DNA fragmentation in apoptotic cells. In brief, cells were fixed with $1 \%$ paraformaldehyde in phosphate-buffered saline (PBS) and placed on ice for $15 \mathrm{~min}$. Subsequently, the samples were treated with a staining solution and incubated at $37^{\circ} \mathrm{C}$ for $60 \mathrm{~min}$. After rinse buffer addition, cells were resuspended in propidium iodide/RNase A solution and incubated at room temperature for $30 \mathrm{~min}$ for a flow cytometry analysis.

MMP evaluation. The MMP was evaluated using the JC-10 Mitochondrial Membrane Potential Assay Kit-Flow Cytometry (ab112133; Abcam). Cells were seeded in $75-\mathrm{cm}^{2}$ flasks (Falcon, Tewksbury, MA, USA), treated with paclitaxel (50 and $100 \mathrm{nM}$ ) or with $0.1 \%$ DMSO as a control for $72 \mathrm{~h}$, trypsinized, washed with PBS and incubated with $1 \mathrm{X} \mathrm{JC-10}$ dye-loading solution at room temperature for $30 \mathrm{~min}$. Cell fluorescence was measured using a BD FACSCantoTM II (BD Biosciences, San Jose, CA, USA).

Annexin V-FITC/PI apoptosis assay. Using an Annexin V-FITC/PI apoptosis detection kit (BioLegend, San Diego, CA, USA), cell apoptosis was detected. In brief, after treatment with paclitaxel (50 and $100 \mathrm{nM}$ ) or with $0.1 \%$ DMSO as a control for $72 \mathrm{~h}$, cells were stained with Annexin V-FITC and PI. They were then analyzed by flow cytometry (FACSCanto ${ }^{\mathrm{TM}}$ II), and their fluorescence intensity was detected. Data were analyzed using the FlowJo software program, version 10.2 (FLOWJO, LLC, Ashland, OR, USA).

Cell cycle analysis. The cells were treated with different concentrations of paclitaxel (50 and $100 \mathrm{nM}$ ) or with $0.1 \%$ DMSO as a control for $72 \mathrm{~h}$. A cell cycle analysis was performed following the Propidium Iodide Cell Cycle Staining Protocol (BioLegend). DNA content was determined with a FACSCanto ${ }^{\text {TM }}$ II. Data were analyzed using the FCS Express 7 Flow software program (De Novo Software, Pasadena, CA, USA).

Western blotting. For 72 h, PC9 cells were treated with different concentrations of paclitaxel (50 and $100 \mathrm{nM}$ ) or with $0.1 \%$ DMSO as a control. Whole protein lysates were isolated using the M-PER mammalian protein extraction reagent (Thermo Scientific), which included a phosphatase inhibitor cocktail and a protease inhibitor cocktail (Sigma-Aldrich). Protein concentrations were assessed 
using the BCA protein assay reagent (Thermo Scientific). Total cellular protein $(50 \mu \mathrm{g})$ was separated by sodium dodecyl sulfatepolyacrylamide gel electrophoresis (SDS-PAGE) and transferred to polyvinylidene fluoride membranes (Bio-Rad Laboratories, Hercules, CA, USA). Milk-blocked blots were incubated at $4^{\circ} \mathrm{C}$ overnight with primary antibodies against the following proteins: Bak, Bcl-2, cleaved caspase-3 (Asp 175), cleaved caspase-9 (Asp 315), PARP, DR5), FADD, Bid, cleaved caspase-8 (Asp 391), Cdk2, Cyclin E1, CDC25A, EGFR, p-EGFR (Thy 1068), PI3K p110 $\alpha$, Akt, p-Akt (Ser 473), mTOR, p-mTOR (Ser 2448), ATR, p-ATR (Ser 428), Chk1, p-Chk1 (Ser 345), $\beta$-actin and $\gamma$-H2AX (ser 139), followed by appropriate horseradish peroxidase-conjugated secondary antibodies. All primary and secondary antibodies were purchased from Cell Signaling Technology, Beverly, MA, USA, except for anti- $\gamma$-H2AX that was obtained from Abcam. Proteins of interest were detected using SuperSignal West Pico PLUS Chemiluminescent Substrate (Thermo Fisher Scientific, Rockford, IL, USA) and viewed using the Invitrogen iBright FL1000 Imaging System (Thermo Fisher Scientific).

Statistical analysis. All data are expressed as the means \pm standard deviation (SD) of three independent experiments and analyzed by a one-way analysis of variance with Dunnett's multiple comparison test or with Sidak's multiple comparison test. All $p$-values $<0.05$ were considered statistically significant. Graphs were created using the GraphPad PRISM 7.0 software program (GraphPad Software Inc., San Diego, CA, USA).

\section{Results}

Cytotoxic effects of paclitaxel in PC9 cells. PC9 cells were treated with 2 concentrations of paclitaxel (50 and $100 \mathrm{nM}$ ) for $72 \mathrm{~h}$, and the WST-1 assay was used to examine the cell viability. The viability of PC9 cells was significantly reduced after paclitaxel exposure compared to the DMSO group (Figure 1A). Paclitaxel-treated cells were stained with Giemsa and DAPI to investigate the morphological changes. As indicated in Figure 1B and C, treating PC9 cells with paclitaxel produced apoptotic features, such as nuclear fragmentation.

Effects of paclitaxel on ROS generation. Many chemotherapy drugs cause an increase in intracellular ROS production, leading to growth inhibition (26-28). Therefore, we hypothesized that paclitaxel would enhance ROS generation. Compared to the DMSO group, paclitaxel increased the ROS level in a concentration-dependent manner (Figure 2A and B). To determine whether or not ROS production plays a role in the anticancer effects of paclitaxel against PC9 cells, ROS inhibitor N-acetyl-L-cysteine (NAC) was added alone or in combination with paclitaxel $(50 \mathrm{nM}$ and $100 \mathrm{nM})$. NAC suppressed ROS production levels, however, not statistically significant, and significantly increased cell proliferation (Figure 2C-E). Taken together, these results suggest that paclitaxel enhances ROS generation, leading to reduced cell proliferation.
Effects of paclitaxel on DNA fragmentation and the DNA damage signaling pathway. Previous studies reported that increased amounts of intracellular ROS could enhance DNA damage $(9,29)$. Therefore, we hypothesized that paclitaxel administration would result in increased DNA fragmentation. To prove that DNA fragmentation was caused by paclitaxel treatment, we conducted a TUNEL assay. As shown (Figure $3 \mathrm{~A}$ ), after $72 \mathrm{~h}$ of paclitaxel treatment, the proportion of fragmented cells increased from $0.27 \%$ to $81.8 \%$, in a dosedependent manner (Figure 3B).

Oxidative DNA damage causes ATR phosphorylation at Ser $428(30,31)$. Activation of this protein promotes phosphorylation of different downstream proteins (including $\mathrm{H} 2 \mathrm{AX}$ and Chk1) and ultimately promotes growth inhibition $(32,33)$. To clarify the precise pathway of the DNA damage response after paclitaxel treatment, we examined the expression of $\gamma$-H2AX, p-Chk1 (Ser 345) and p-ATR (Ser 428), as these proteins are responsible for activating the DNA damage pathway. As shown (Figure 3C), the expression of $\gamma$-H2AX, p-Chk1 (Ser 345) and p-ATR (Ser 428) was markedly increased after paclitaxel treatment compared with the DMSO group. These results suggest that paclitaxel induced DNA damage in PC9 cells via ATR-Chk1 signaling axis activation.

Effects of paclitaxel on MMP. Previous studies have reported that ROS production can alter the MMP and structure (34, 35). To determine whether or not paclitaxel affected the MMP, we performed an MMP assay. As shown in Figure 4, the loss of MMP increased from $1.67 \%$ to $36.1 \%$ (lower right quadrant 3) in PC9 cells after paclitaxel treatment, indicating that the anticancer effect of paclitaxel is, at least in part, due to paclitaxel-induced MMP loss.

Effects of paclitaxel on apoptosis and the apoptosis signaling pathways in PC9 cells. Chemotherapy drugs can inhibit cell proliferation and induce apoptosis in human cancer cells (3638). To confirm that the cell death caused by paclitaxel was indeed apoptosis, we performed Annexin V and PI staining for a flow cytometry analysis. As shown (Figure 5A), after $72 \mathrm{~h}$ of exposure to paclitaxel, a significant increase in early apoptotic and necrotic cells as well as an increase in the proportion of late apoptotic cells from $3.72 \%$ to $60.6 \%$. Flow cytometry results showed that the paclitaxel-induced apoptosis was concentration-dependent (Figure 5B).

Chemotherapeutic agents induce apoptosis through extrinsic/intrinsic apoptotic pathway activation $(39,40)$. To examine whether or not the extrinsic apoptotic pathway regulates the apoptotic impact of paclitaxel, we evaluated several extrinsic apoptotic proteins. As shown in Figure 5C, the expression of tBid, DR5 and cleaved caspase- 8 (Asp 391) was increased by paclitaxel treatment in PC9 cells. In contrast, paclitaxel induced intrinsic mitochondria-dependent 
A

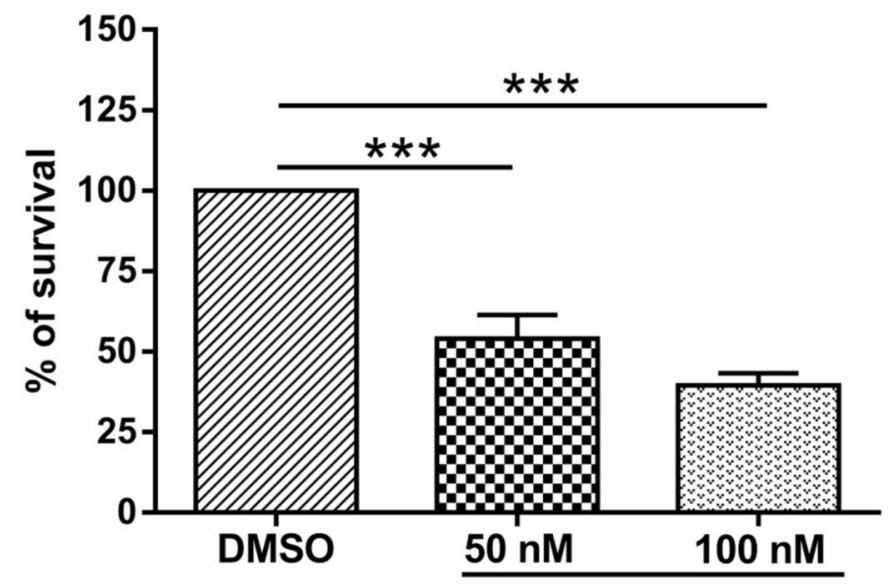

B

DMSO

Paclitaxel 50 nM

Paclitaxel 100 nM
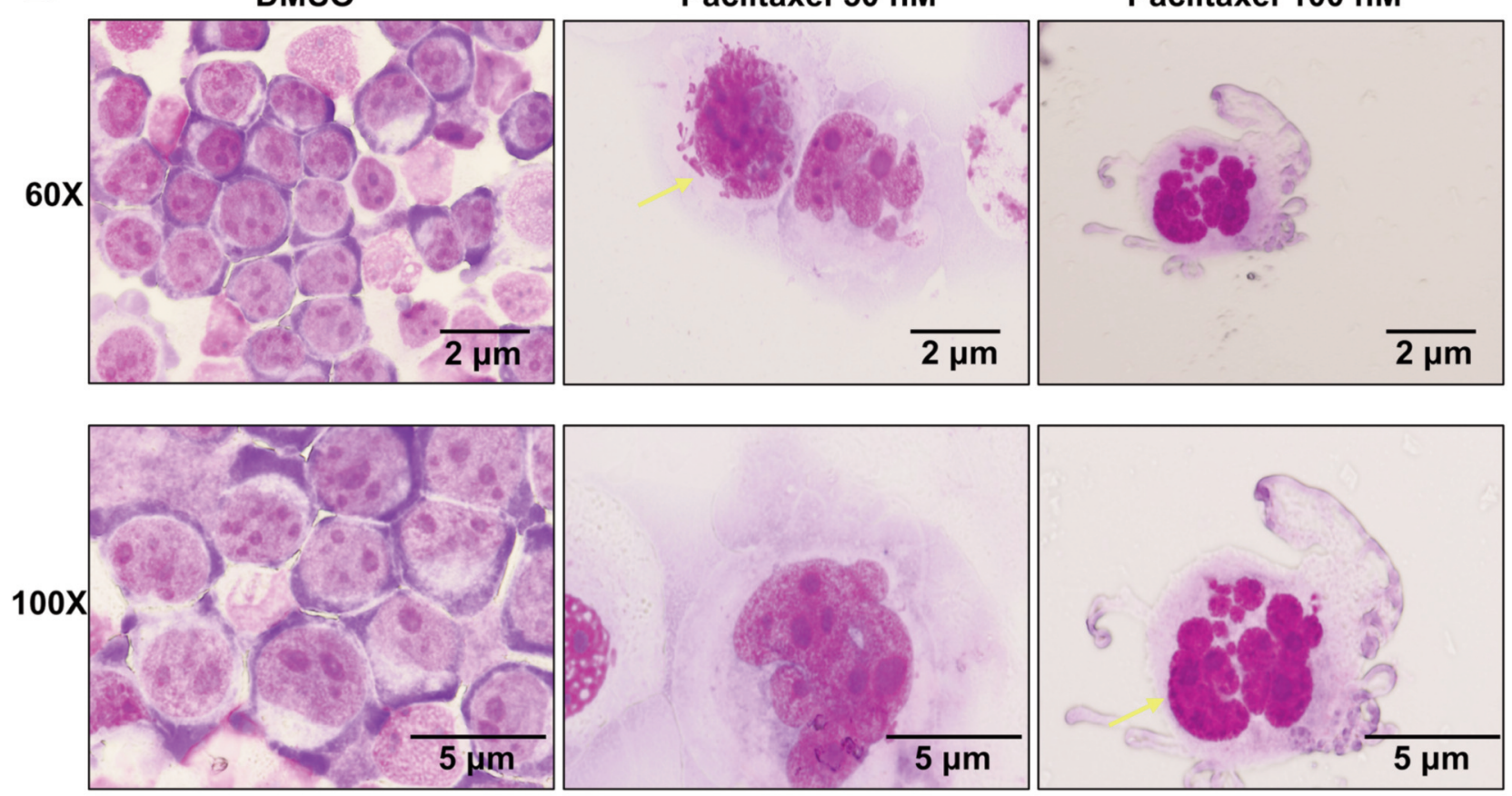

C

DMSO

Paclitaxel 50 nM

Paclitaxel 100 nM
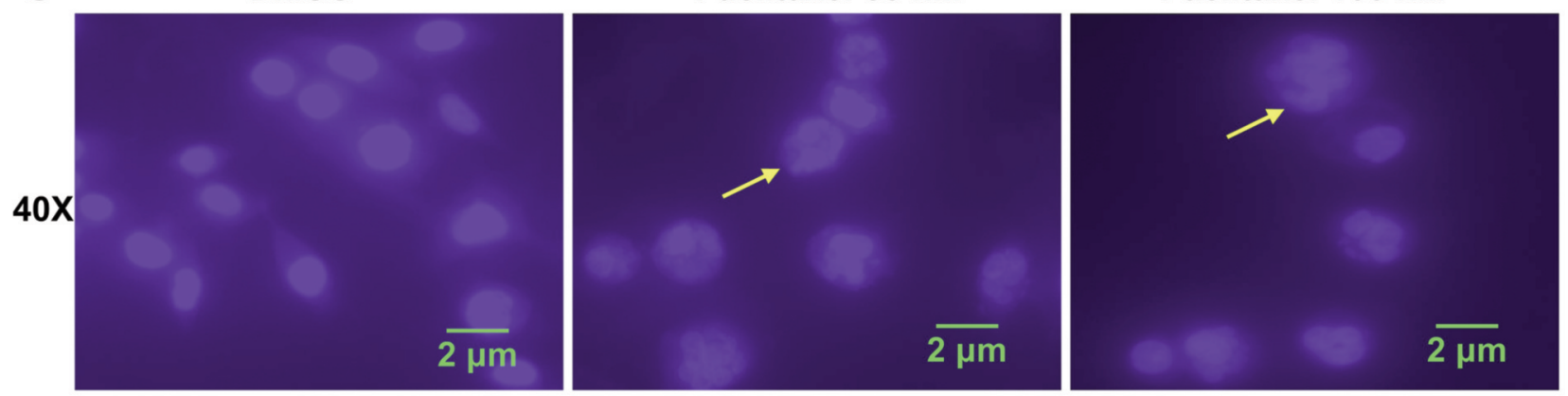

Figure 1. Effects of paclitaxel on the viability and morphology of PC9 cells. (A) The WST-1 cell proliferation assay was used to evaluate the viability of PC9 cells treated with different concentrations of paclitaxel for $72 \mathrm{~h}$. A one-way ANOVA with Dunnett's multiple comparison test determined the significance: $* * * p<0.001$ compared with the DMSO-treated group. (B) DAPI and (C) Giemsa staining of PC9 cells were treated with different paclitaxel concentrations for $72 \mathrm{~h}$. The yellow arrows in paclitaxel-treated cells indicated nuclear fragmentation. 


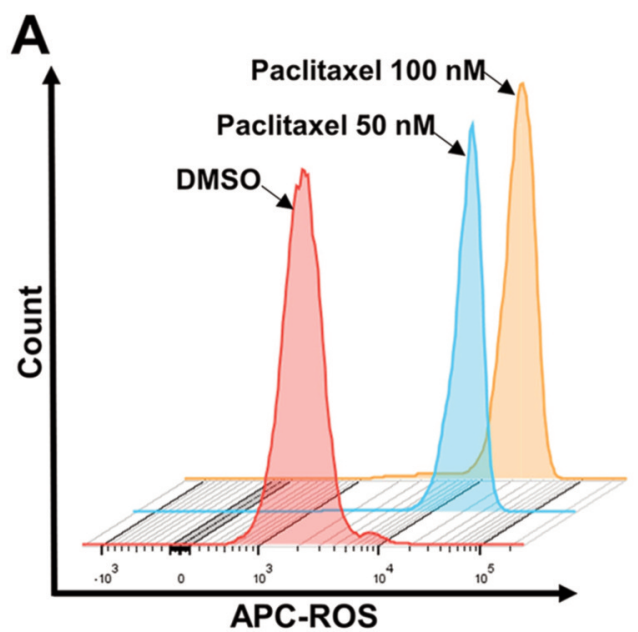

B
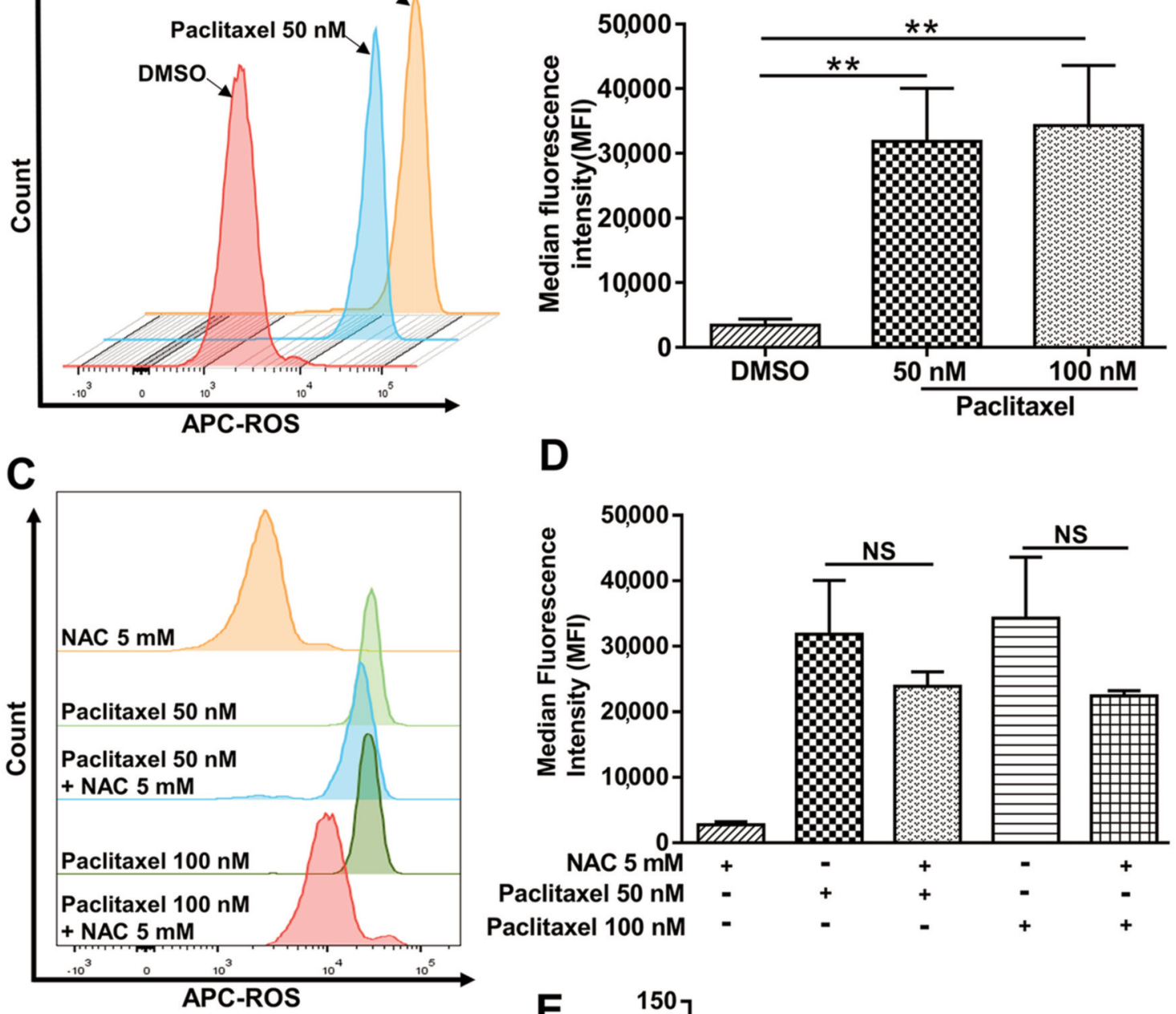

D
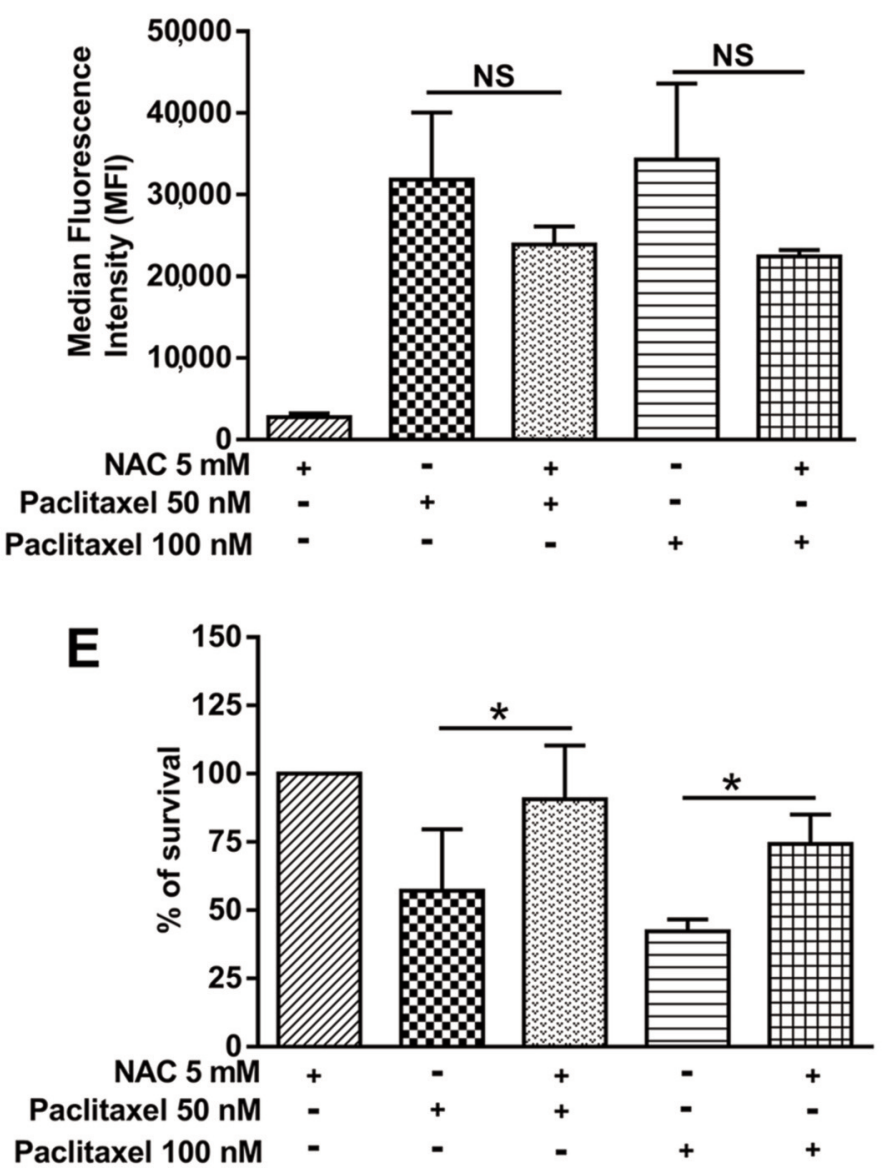

Figure 2. Effects of paclitaxel on ROS generation. (A) PC9 cells incubated with paclitaxel at different concentrations (or 0.1\% DMSO as a control) for $72 \mathrm{~h}$ were stained with ROS deep red dye. The histogram shows that the ROS levels increased in a concentration-dependent manner. (B) The bar diagram shows that the ROS production increased in a dose-dependent manner. A one-way ANOVA with Dunnett's multiple comparison test determined the significance: ${ }^{* *} p<0.01$ compared with the DMSO-treated group. (C) After treatment with paclitaxel for $72 \mathrm{~h}$ in the absence or presence of NAC, cells were stained with ROS deep red dye. (D) The bar diagram shows the quantification of mitochondrial ROS production. Comparisons were made between the control group and experimental group using a one-way ANOVA followed by Sidak's multiple comparison test. NS, not significant. (E) After $72 \mathrm{~h}$ of treatment with paclitaxel in the absence or presence of NAC, the cell viability was analyzed by the WST-1 cell proliferation assay. Comparisons were made between the control group and experimental group using a one-way ANOVA followed by Sidak's multiple comparison test. Data are presented as mean \pm SD from three technical replicates. ${ }^{*} p<0.05$. 

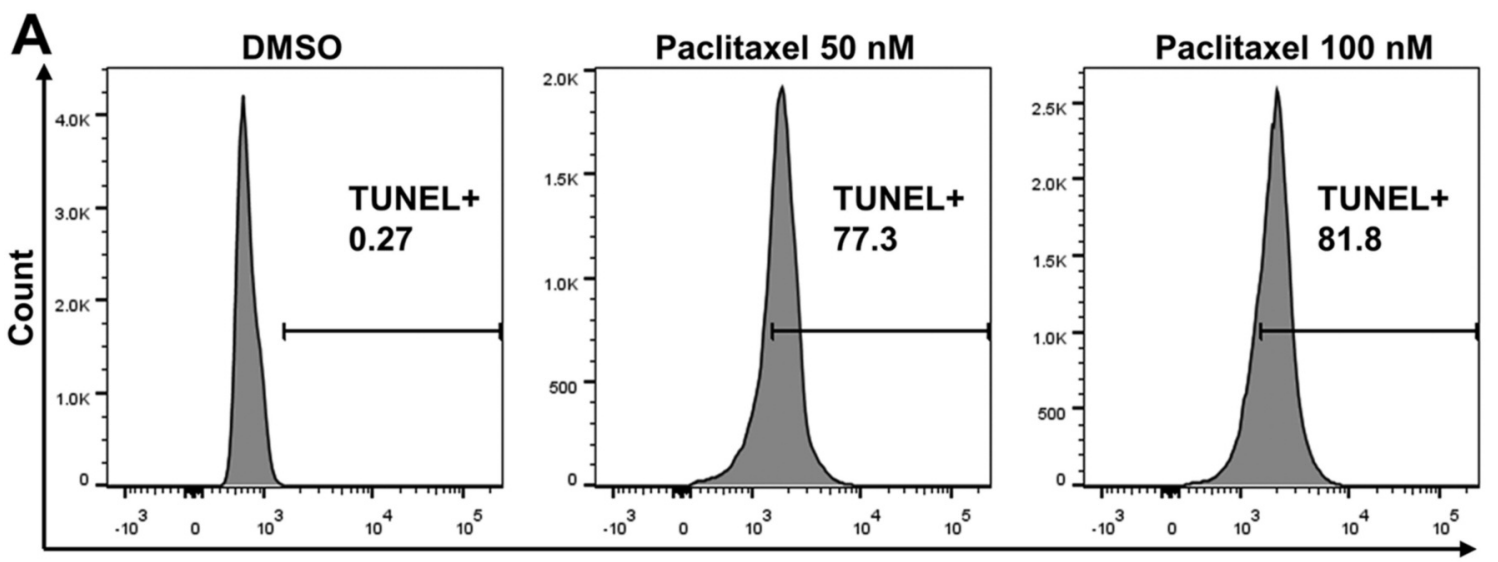

B

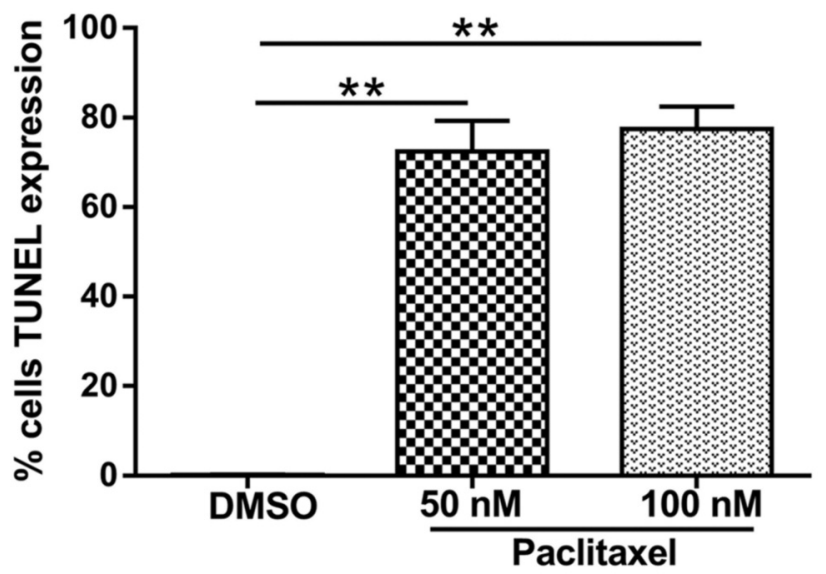

FITC-TUNEL

C

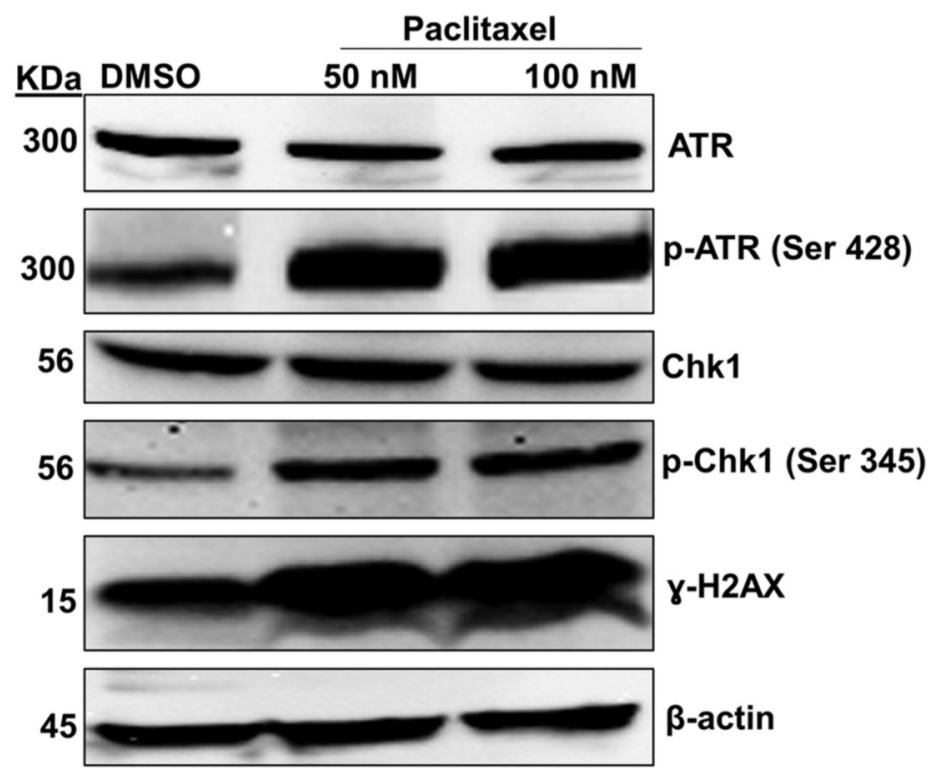

Figure 3. Effects of paclitaxel on DNA fragmentation and the DNA damage signaling pathway. (A) PC9 cells were stained with fluorescein isothiocyanate-dUTP dye after incubation with paclitaxel at different concentrations for $72 \mathrm{~h}$. Flow cytometry measured the fluorescence signal. Histograms show that DNA fragmentation increased in a concentration-dependent manner. (B) The percentage of cells expressing TUNEL increased in a dose-dependent manner, as represented in the bar graph. Results are the mean $\pm S D$ of three independent experiments. Significance was determined by a one-way ANOVA followed by Dunnett's multiple comparison test. ${ }^{*} p<0.01$. (C) Total cell lysates from control and paclitaxeltreated PC9 cells for $72 \mathrm{~h}$ were subjected to Western blotting with the antibodies against ATR, p-ATR (Ser 428), Chk1, p-ChK1 (Ser 345) and $\gamma$ $H 2 A X$. $\beta$-actin served as a loading control. All images shown here are representative of three independent experiments with similar results. 


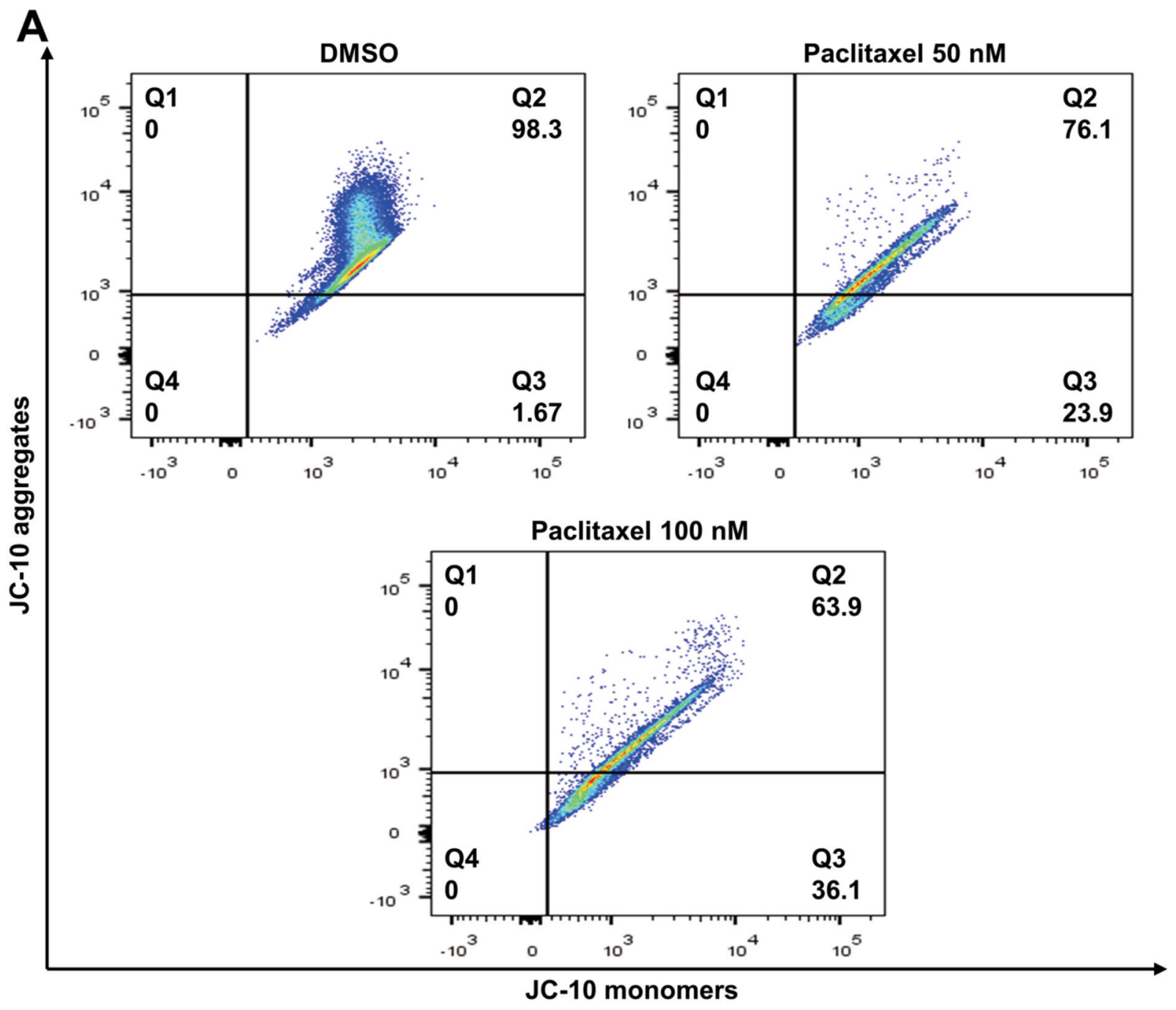

B

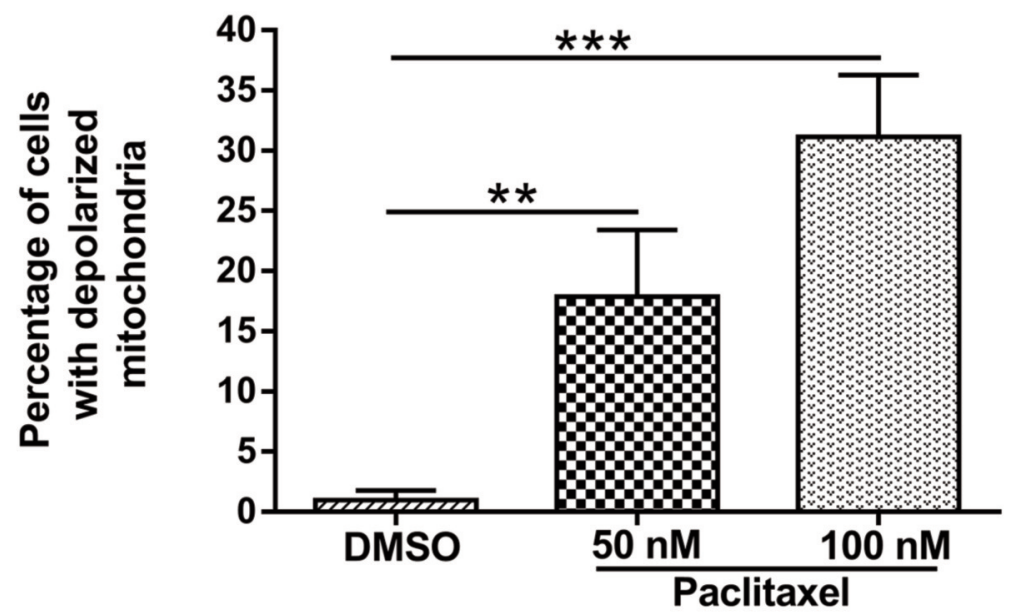

Figure 4. Effects of paclitaxel on the mitochondrial membrane potential (MMP). (A) For 72 h, PC9 cells were treated with different concentrations of paclitaxel. Before the flow cytometry analysis, cells were stained with JC-10 dye. Representative results from three independent experiments. (B) Quantitative data are used from the green monomer fluorescence (depolarized MMP) of JC-10. Results are presented as the mean $\pm S D$ of three independent measurements. A one-way ANOVA with Dunnett's multiple comparison test determined the significance: $* * p<0.01$ and $* * * p<0.001$ compared with the DMSO-treated group. 
A

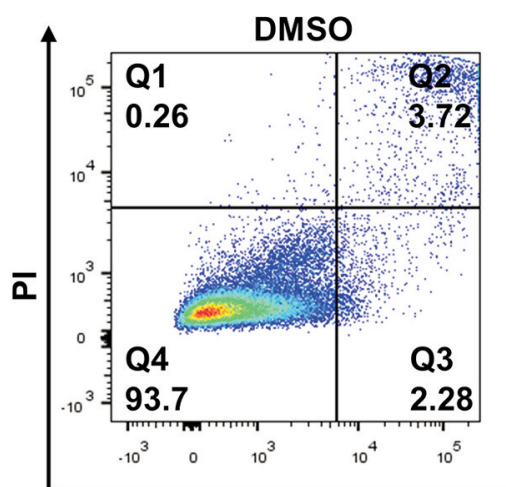

Paclitaxel $50 \mathrm{nM}$

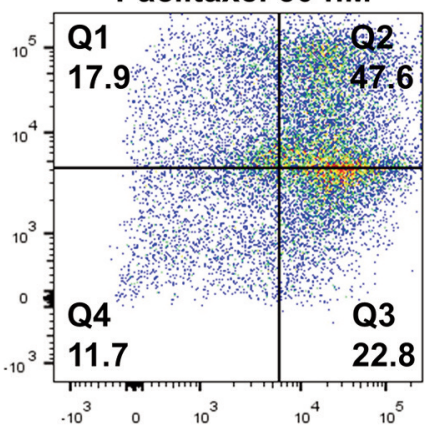

Paclitaxel $100 \mathrm{nM}$

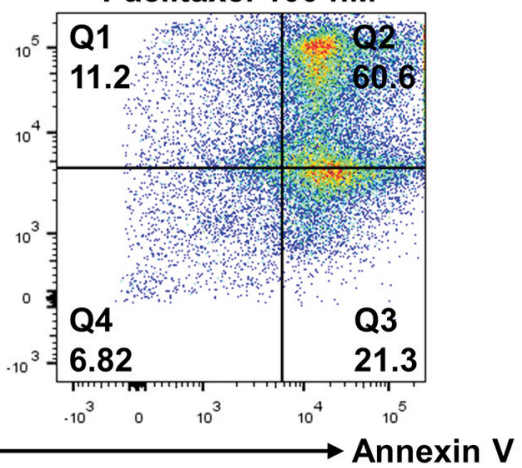

B

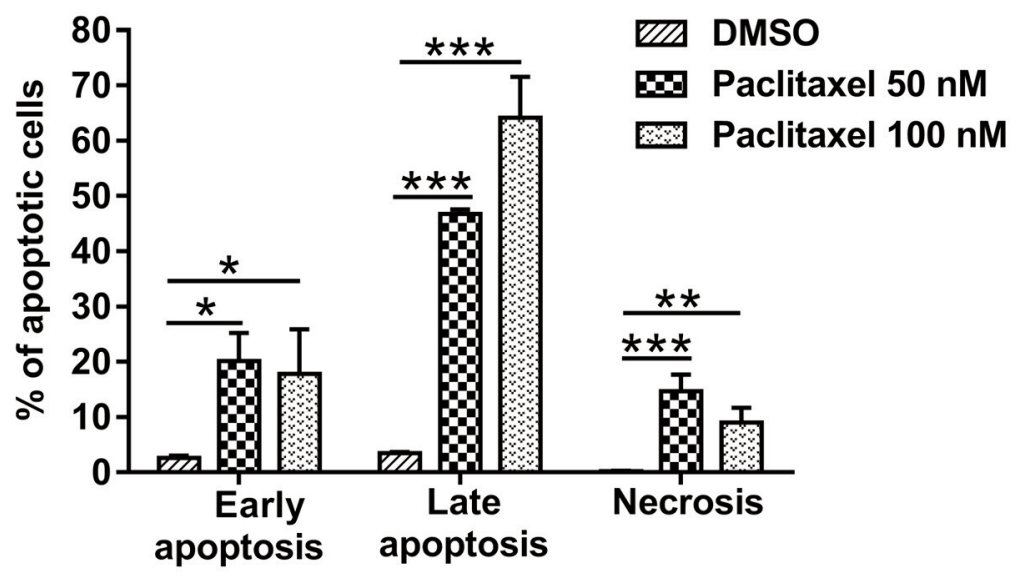

C
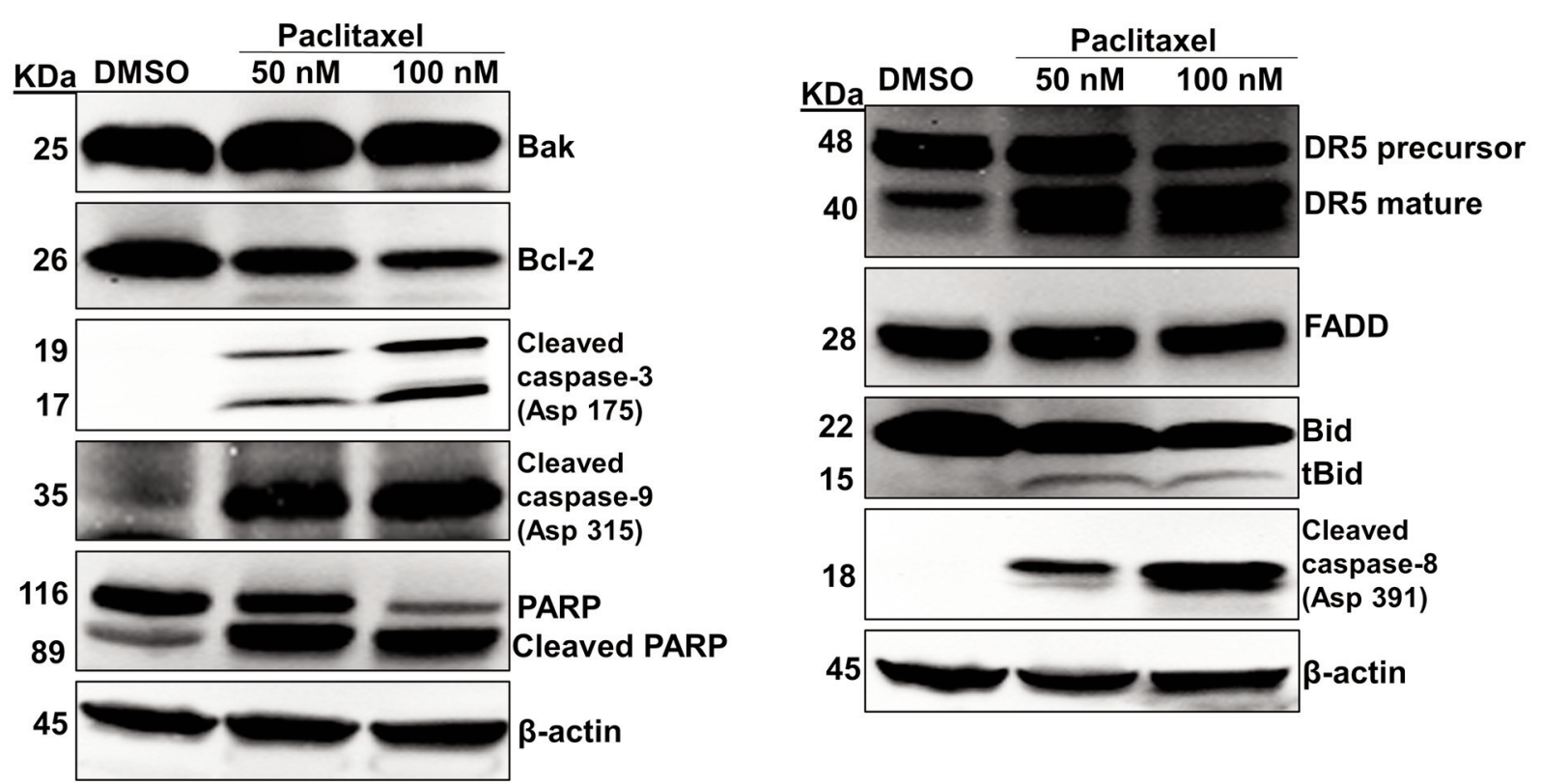

Figure 5. Effects of paclitaxel on the induction of apoptosis in PC9 cells. (A) PC9 cells were treated with 2 concentrations of paclitaxel (50 and $100 \mathrm{nM}$ ) for $72 \mathrm{~h}$, and flow cytometry was used to evaluate apoptosis. Quadrant 1 shows necrotic cells; Quadrant 2 shows late-apoptotic cells; Quadrant 3 shows early apoptotic cells; Quadrant 4 shows viable cells. (B) A bar diagram illustrates the percentage of apoptotic cells. The values were calculated as the mean $\pm S D$ from three independent experiments. Significance was determined by a one-way ANOVA followed by Dunnett's multiple comparison test: $* p<0.05, * * p<0.01$ and $* * * p<0.001$ compared with the DMSO-treated group. (C) To assess the expression of Bak, Bcl2, cleaved caspase-3 (Asp 175), cleaved caspase-9 (Asp 315), PARP, DR5, FADD, Bid and cleaved caspase-8 (Asp 391) proteins, Western blotting was performed. $\beta$-actin served as a loading control. All images shown here are representative of three independent experiments with similar results. 
apoptosis, evidenced by Bak up-regulation and Bcl-2 downregulation (Figure 5C). Taken together, these results suggest that paclitaxel activates extrinsic and intrinsic apoptotic pathways to impede PC9 cell proliferation.

In the intrinsic and extrinsic pathways of apoptosis, signaling determines the activation of caspases that act on the proteolytic cleavage of PARP, which is a hallmark of apoptosis $(41,42)$. To clarify the apoptotic mechanism induced by paclitaxel treatment in PC9 cells, the expression of cleaved caspase-9 (Asp 315), cleaved caspase-3 (Asp 175) and cleaved PARP was evaluated. As shown in Figure 5C PC9 cells treated with paclitaxel showed a higher expression of cleaved caspase-9 (Asp 315), cleaved caspase-3 (Asp 175) and cleaved PARP than the control. These results suggest that paclitaxel activates a caspase cascade to induce apoptosis in PC9 cells.

Effects of paclitaxel on cell cycle arrest. Previous studies reported that DNA damage could induce cell cycle arrest (43, 44). As indicated in Figure 6A, treatment with paclitaxel resulted in $G_{1}$ phase block in $96.37 \%$ of the population, suggesting that paclitaxel caused cell cycle arrest in the $\mathrm{G}_{1}$ phase.

The $\mathrm{G}_{1} / \mathrm{S}$ checkpoint confirms that all DNA damage has been repaired, and the cell is ready to start replication (43, 45). DNA damage activates the ATM/ATR pathway, leading to inhibition of the $\mathrm{CDC} 25 \mathrm{~A}$ phosphatase and thereby preventing Cdk2 activity and disrupting DNA replication (46-48). In addition, CDC25A phosphatase plays a vital role in activating the Cyclin E/Cdk2 complex, which is crucial for initiating $G_{1}$ to $S$ phase transition (49). To further evaluate our cell cycle analysis data, we examined the expression of CDC25A, Cyclin E1 and Cdk2. Western blotting showed a decreased expression of CDC25A, Cyclin E1 and Cdk2 (Figure 6C), suggesting that these proteins may be involved in the cell cycle arrest of PC9 cells.

Effects of paclitaxel on the EGFR/PI3K/Akt/mTOR signaling pathway. Activated homodimerized EGFR leads to the activation of intracellular cascades, such as PI3K/Akt/mTOR (50). Consequently, the activated PI3K/AKT $/ \mathrm{mTOR}$ signaling pathway triggers protein synthesis (51). The EGFR/PI3K/Akt/mTOR signaling cascade plays a crucial role in numerous cellular processes, including metabolism and cell proliferation (52). To evaluate whether or not paclitaxel impedes EGFR/PI3K/AKT/mTOR signaling pathway, we checked the expression of EGFR, p-EGFR (Thy 1068), PI3K p110 $\alpha$, Akt, p-Akt (Ser 473), mTOR and pmTOR (Ser 2448). Western blotting showed a decrease in the expression of EGFR, p-EGFR (Thy 1068), PI3K p110 $\alpha$, Akt, p-Akt (Ser 473), mTOR and p-mTOR (Ser 2448) (Figure 7). These results suggest that inhibition of the EGFR/PI3K/ Akt/mTOR signaling pathway is involved in the anticancer effects of paclitaxel in EGFR-mutated PC9 cells.

\section{Discussion}

Paclitaxel is a well-known anticancer drug, but the mechanism underlying its effects on PC9 cells remains unknown. We therefore evaluated the extent of PC9 cell death mediated by paclitaxel and clarified the mechanisms of actions. Based on the findings of this study, we proposed a model of the major mechanism of activation of intrinsic and extrinsic pathways of apoptosis, G1 phase arrest, and inhibition of the EGFR/PI3K/AKT/mTOR signaling pathway by paclitaxel in EGFR-mutated PC9 cells (Figure 8).

Pro-apoptotic proteins (such as Bak, Bax) and anti-apoptotic proteins (such as $\mathrm{Bcl}-2, \mathrm{Bcl}-\mathrm{xL}$ ) are important upstream molecules that respond to intrinsic apoptosis $(53,54)$. A reduced $\mathrm{Bak} / \mathrm{Bcl}-2$ ratio is closely associated with the destruction of the MMP (55). An increase in the intracellular ROS level leads to the loss of MMP, resulting in the release of cytochrome c from the mitochondria into the cytosol (34). Cytochrome c binds with Apaf-1 to form an apoptosome and activates apoptosis, initiating procaspase-9 (56). Thus, activated caspase-9 can cleave and directly activate other effector caspases, such as caspase-3 (57). The initiation of a caspase cascade plays a vital role in apoptosis (42). Activated caspase3 is the final step in the cascade that triggers apoptosis through the proteolytic cleavage of PARP (58). This current study demonstrated that paclitaxel enhanced MMP loss and caspase cascade activation to induce apoptosis (Figures 4 and 5).

The oxidative pressure created by ROS can damage parts of the cell, including DNA and proteins (59). Failure to repair cellular DNA damage by an adequate repair mechanism can cause cell death due to double-stranded DNA breakdown (60). ROS can induce cell death by initiating various DNA damage response pathways, such as ATM/Chk2 and ATR/Chk1 (9). Several studies reported that $\gamma$-H2AX formation is a sensitive indicator of DNA replication stress or DNA damage $(61,62)$. Some studies have reported that during apoptosis, the ATR/Chk1 pathway is activated by caspase-dependent cleavage $(63,64)$. The present study showed that paclitaxel increased ROS production, resulting in the activation of the ATR/Chk1 pathway as well as that of mitochondria-dependent caspase (Figures 2 and 3).

The TNF receptor, DR4 [TRAILR1] and DR5 [TRAILR2] receptors, Fas receptor and FADD adaptor constitute the DISC $(65,66)$. Several studies have reported that DNA damage leads to the activation of the extrinsic pathway by activating the DR4 and DR5 receptors (67-69). The pro-apoptotic cytoplasmic protein Bid connects the intrinsic and extrinsic pathway, which is cleaved by the activated caspase- 8 generated by the DISC $(42,70)$. Activated caspase- 8 can also directly cleave caspase-3 to enhance downstream apoptotic signals $(57,71)$. Once the generation of truncated Bid (tBid) is induced by activated caspase- 8 , the tBid advances until the mitochondrial membrane interacts with the Bax, Bak and Bad 

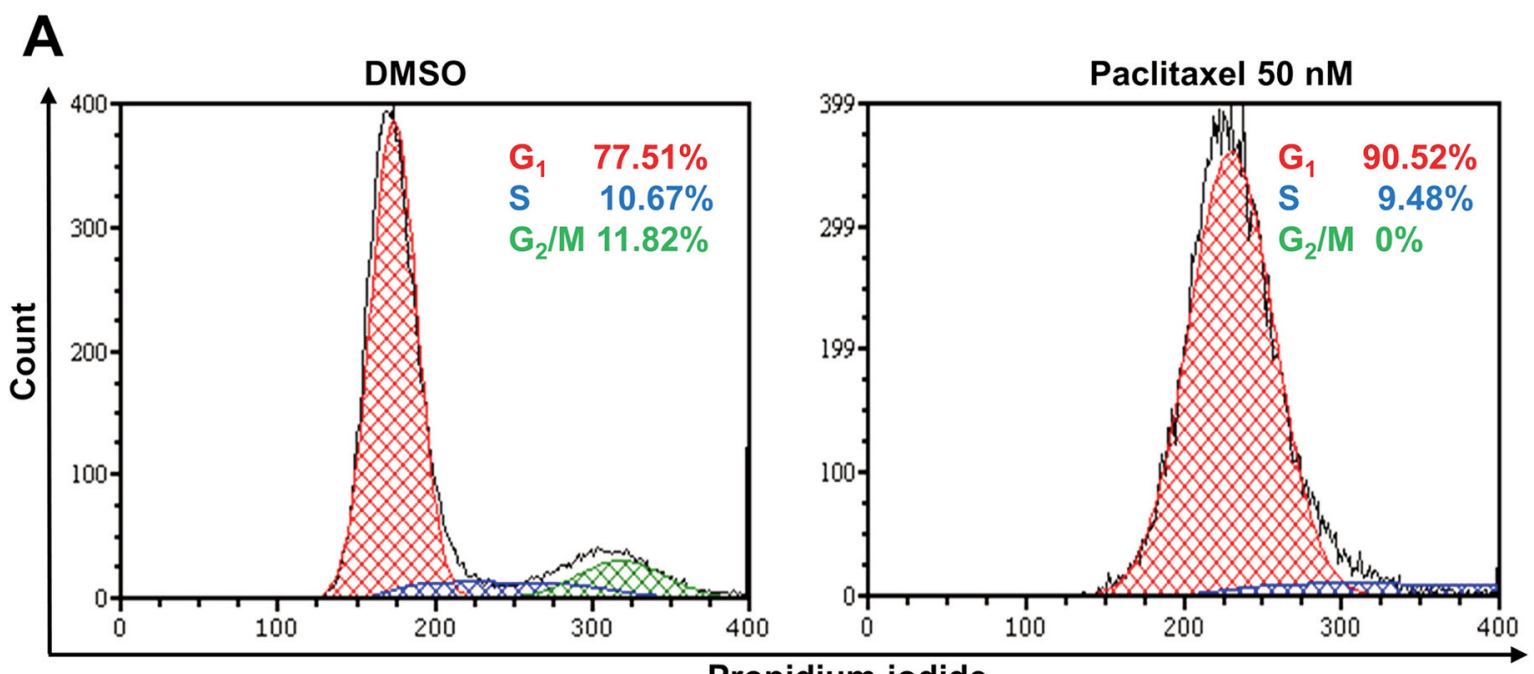

Propidium iodide
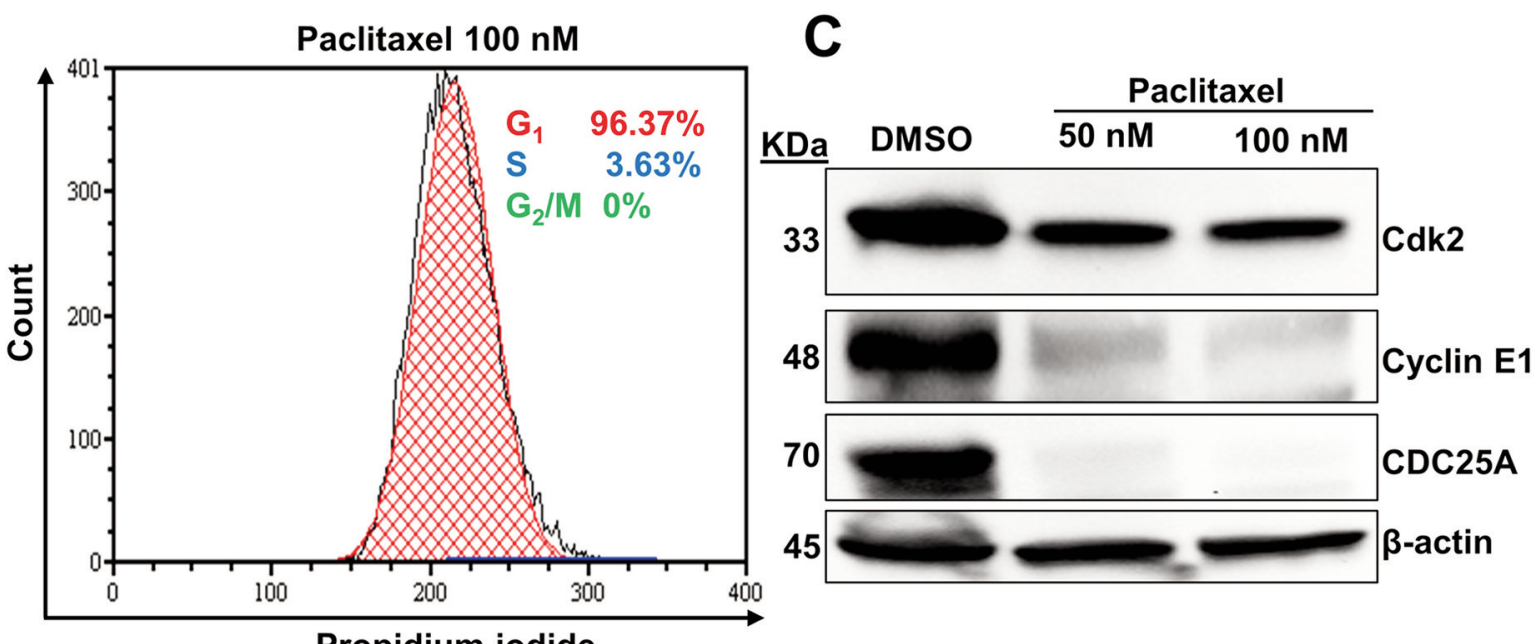

B

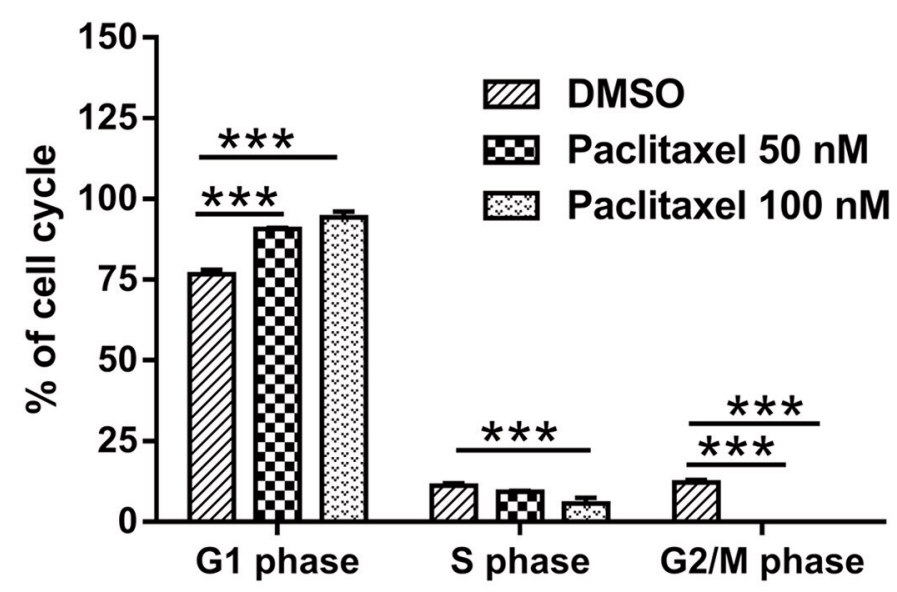

Figure 6. Effects of paclitaxel on cell cycle regulation in PC9 cells. (A) Flow cytometry showed that paclitaxel induced cell cycle arrest in PC9 cells. (B) The bar graph represents the cell cycle distribution of PC9 cells. In the G1 phase, the proportion of PC9 cells increased after 72 h of treatment with paclitaxel. Results are presented as the mean $\pm S D$ of three independent experiments. A one-way ANOVA with Dunnett's multiple comparison test determined the significance: ${ }^{* * *} p<0.001$ compared with the DMSO-treated group. (C) PC9 cells were treated with paclitaxel for $72 \mathrm{~h}$. The expression of CDC25A, Cyclin E1 and Cdk2 proteins was evaluated by Western blotting. $\beta$-actin was used as a loading control. All images shown here are representative of three independent experiments with similar results. 
proteins and induces mitochondrial permeabilization, resulting in the release of cytochrome c (72-74). The present study showed that ROS-mediated DNA damage triggered the activation of the apoptotic death receptor pathway via the upregulation of DR5, resulting in the activation of caspase- 8 to induce mitochondrial permeabilization.

DNA damage leads to the activation of the ATM/Chk2 and ATR/Chk1 pathway, resulting in the inhibition of CDC25A $(75,76) . \mathrm{CDC} 25 \mathrm{~A}$ is a phosphatase that can activate the cyclin E/Cdk2 complex, resulting in $\mathrm{G} 1$ to $\mathrm{S}$ phase transition (49). The present study showed that paclitaxel induced G1 phase arrest in response to DNA damage (Figure 6).

EGFR activation in response to ligands triggers several intracellular cascades, such as PI3K/AKT/mTOR and RAS/MAPK(ERK) $(77,78)$. The EGFR/PI3K/Akt/mTOR signaling cascade is crucial for protein synthesis and cell proliferation $(77,79)$. The present study revealed that paclitaxel effectively inhibited the EGFR/PI3K/AKT/mTOR signaling pathway and impeded cell proliferation (Figure 7).

Paclitaxel can bind to microtubules and prevent the normal dynamic reorganization of the microtubule network, which plays a crucial role in inhibiting cell proliferation (80). Various studies indicated that the binding site for paclitaxel is the beta-tubulin subunit $(81,82)$. Paclitaxel has been reported to arrest the cell cycle in the $G_{1}$ and $G_{2} / M$ phases and induce cell death in cancer by stabilizing the microtubule polymer and preventing depolymerization $(83,84)$. This mechanism of action may also be involved in the effect of paclitaxel on cell cycle, in our study. However, further studies are needed to clarify the entire mechanism of microtubule stabilization by paclitaxel in EGFR-mutated PC9 cells.

Taken together, our results provide a basis for selecting paclitaxel chemotherapy for patients with EGFR-mutated NSCLC. We suggest that our current findings have broad implications for a clear understanding of ROS-mediated growth inhibition not only in EGFR mutant tumors but also in other oncogene-driven tumors.

\section{Conclusion}

Paclitaxel impeded the proliferation of PC9 cells in three explicit systems. First, paclitaxel increased ROS-mediated DNA damage, which triggered the activation of the extrinsic and intrinsic apoptotic signaling pathways. Second, paclitaxelinduced $G_{1}$ phase arrest was associated with the activation of ATR/Chk1 signaling. Third, paclitaxel inhibited the EGFR/PI3K/AKT/mTOR signaling pathway to prevent cell proliferation. Therefore, paclitaxel exerted a significant anticancer effect on PC9 NSCLC cells.

\section{Conflicts of Interest}

The Authors declare no competing financial interests.

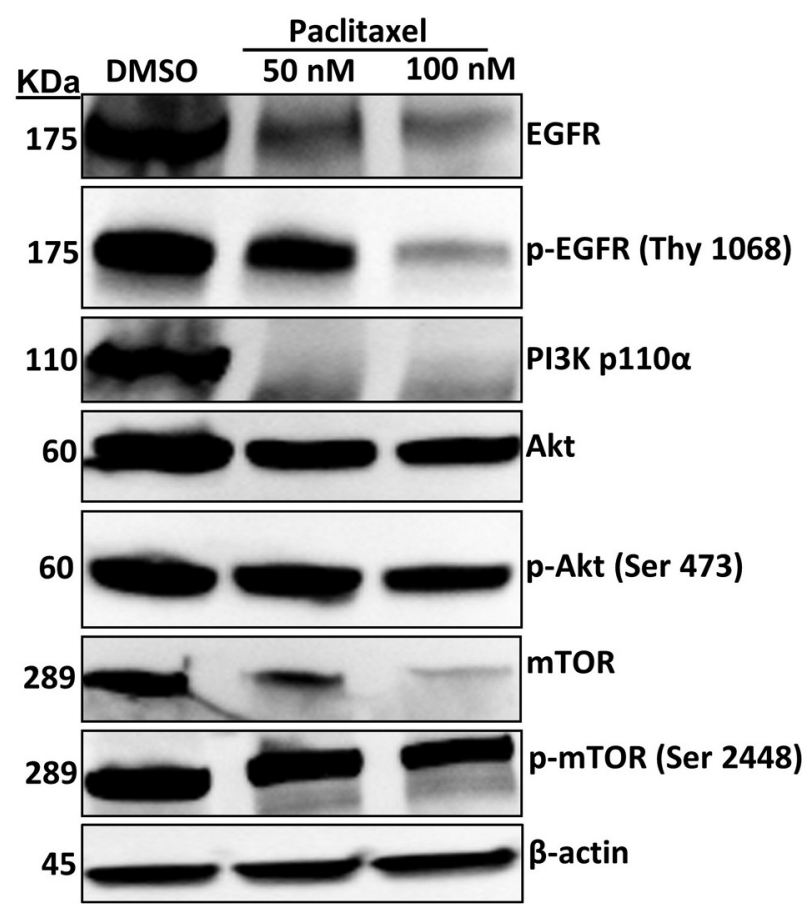

Figure 7. Effects of paclitaxel on EGFR/PI3K/Akt/mTOR signaling regulation. PC9 cells were treated with different concentrations of paclitaxel for $72 \mathrm{~h}$, and the expression of EGFR, p-EGFR (Thy 1068),

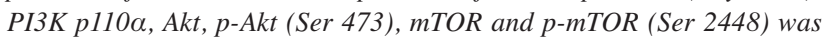
evaluated by Western blotting. $\beta$-actin was used as a loading control. All images shown here are representative of three independent experiments with similar results.

\section{Authors' Contributions}

Md Mohiuddin and Kazuo Kasahara conceived this study; Md Mohiuddin carried out the experiments; Md Mohiuddin and Kazuo Kasahara discussed and interpreted the results; Md Mohiuddin wrote the manuscript; Kazuo Kasahara supervised the experiments and project.

\section{Acknowledgements}

We would like to thank Ms. Miki Kashiwano (Department of Respiratory Medicine, Graduate School of Medical Sciences, Kanazawa University) for her technical assistance. This work was supported by Grant-in-Aid for Scientific Research (C) (JSPS KAKENHI Grant Number 17K09606) to K.K. The funders had no role in the study design, data collection, or interpretation or decision to submit the work for publication.

\section{References}

1 Humphrey LL, Deffebach M, Pappas M, Baumann C, Artis K, Mitchell JP, Zakher B, Fu R and Slatore CG: Screening for lung cancer with low-dose computed tomography: a systematic review to update the US Preventive services task force 


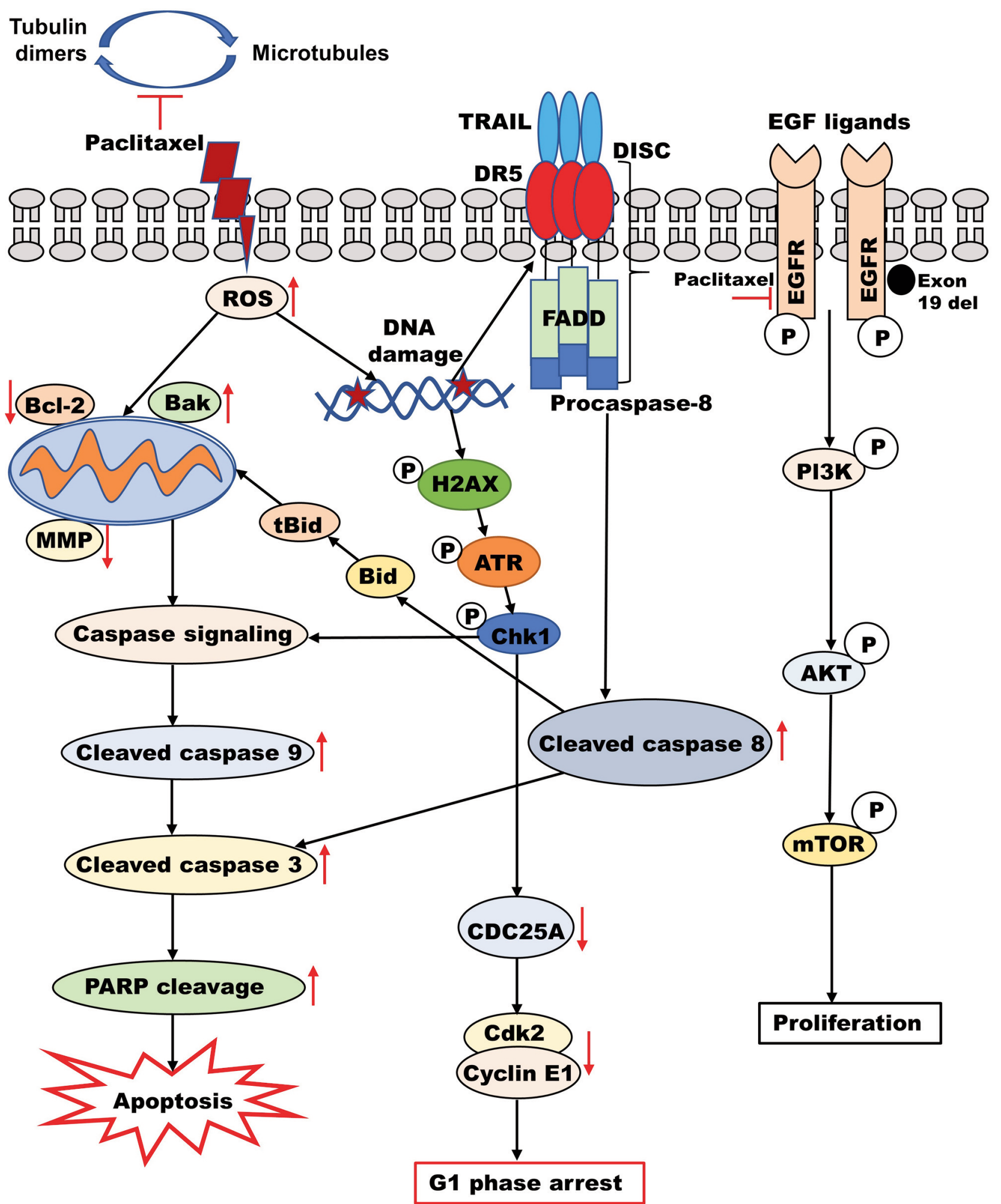

Figure 8. A schematic illustration of the proposed mechanisms for paclitaxel-induced growth inhibition in PC9 cells. 
recommendation. Ann Intern Med 159(6): 411-420, 2013. PMID: 23897166. DOI: 10.7326/0003-4819-159-6-201309170-00690

2 Molina JR, Yang P, Cassivi SD, Schild SE and Adjei AA: Nonsmall cell lung cancer: epidemiology, risk factors, treatment, and survivorship. Mayo Clin Proc 83(5): 584-594, 2008. PMID: 18452692. DOI: $10.4065 / 83.5 .584$

3 Chu Q, Vincent M, Logan D, Mackay JA, Evans WK and Lung Cancer Disease Site Group of Cancer Care Ontario's Program in Evidence-based Care: Taxanes as first-line therapy for advanced non-small cell lung cancer: a systematic review and practice guideline. Lung Cancer 50(3): 355-374, 2005. PMID: 16139391 DOI: $10.1016 /$ j.lungcan.2005.06.010

4 Wiseman LR and Spencer CM: Paclitaxel. An update of its use in the treatment of metastatic breast cancer and ovarian and other gynaecological cancers. Drugs Aging 12(4): 305-334, 1998. PMID: 9571394. DOI: 10.2165/00002512-199812040-00005

5 Redza-Dutordoir $M$ and Averill-Bates DA: Activation of apoptosis signalling pathways by reactive oxygen species. Biochim Biophys Acta 1863(12): 2977-2992, 2016. PMID: 27646922. DOI: 10.1016/j.bbamcr.2016.09.012

6 Liou GY and Storz P: Reactive oxygen species in cancer. Free Radic Res 44(5): 479-496, 2010. PMID: 20370557. DOI: $10.3109 / 10715761003667554$

7 Nita M and Grzybowski A: The role of the reactive oxygen species and oxidative stress in the pathomechanism of the agerelated ocular diseases and other pathologies of the anterior and posterior eye segments in adults. Oxid Med Cell Longev 2016: 3164734, 2016. PMID: 26881021. DOI: 10.1155/2016/3164734

8 Matsuoka S, Ballif BA, Smogorzewska A, McDonald ER 3rd, Hurov KE, Luo J, Bakalarski CE, Zhao Z, Solimini N, Lerenthal Y, Shiloh Y, Gygi SP and Elledge SJ: ATM and ATR substrate analysis reveals extensive protein networks responsive to DNA damage. Science 316(5828): 1160-1166, 2007. PMID: 17525332. DOI: $10.1126 /$ science. 1140321

9 Srinivas US, Tan BWQ, Vellayappan BA and Jeyasekharan AD: ROS and the DNA damage response in cancer. Redox Biol 25: 101084, 2019. PMID: 30612957. DOI: 10.1016/j.redox.2018.101084

10 Herranz $\mathrm{N}$ and Gil J: Mechanisms and functions of cellular senescence. J Clin Invest 128(4): 1238-1246, 2018. PMID: 29608137. DOI: $10.1172 / J C I 95148$

11 Hsieh CL, Liu CM, Chen HA, Yang ST, Shigemura K, Kitagawa K, Yamamichi F, Fujisawa M, Liu YR, Lee WH, Chen KC, Shen CN, Lin CC, Chung LWK and Sung SY: Reactive oxygen speciesmediated switching expression of MMP-3 in stromal fibroblasts and cancer cells during prostate cancer progression. Sci Rep 7(1): 9065, 2017. PMID: 28831065. DOI: 10.1038/s41598-017-08835-9

$12 \mathrm{Kim} \mathrm{R}$, Emi $\mathrm{M}$ and Tanabe K: Caspase-dependent and independent cell death pathways after DNA damage (Review). Oncol Rep 14(3): 595-599, 2005. PMID: 16077961.

13 Ashkenazi A and Dixit VM: Death receptors: signaling and modulation. Science 281(5381): 1305-1308, 1998. PMID: 9721089. DOI: 10.1126/science.281.5381.1305

14 Pan G, O'Rourke K, Chinnaiyan AM, Gentz R, Ebner R, Ni J and Dixit VM: The receptor for the cytotoxic ligand TRAIL. Science 276(5309): 111-113, 1997. PMID: 9082980. DOI: 10.1126/science.276.5309.111

15 Pan G, Ni J, Wei YF, Yu G, Gentz R and Dixit VM: An antagonist decoy receptor and a death domain-containing receptor for TRAIL. Science 277(5327): 815-818, 1997. PMID: 9242610. DOI: $10.1126 /$ science.277.5327.815
16 Walczak H, Degli-Esposti MA, Johnson RS, Smolak PJ, Waugh JY, Boiani N, Timour MS, Gerhart MJ, Schooley KA, Smith CA, Goodwin RG and Rauch CT: TRAIL-R2: a novel apoptosismediating receptor for TRAIL. EMBO J 16(17): 5386-5397, 1997. PMID: 9311998. DOI: 10.1093/emboj/16.17.5386

17 Medema JP, Scaffidi C, Kischkel FC, Shevchenko A, Mann M, Krammer PH and Peter ME: FLICE is activated by association with the CD95 death-inducing signaling complex (DISC). EMBO J 16(10): 2794-2804, 1997. PMID: 9184224. DOI: 10.1093/emboj/16.10.2794

18 Boldin MP, Goncharov TM, Goltsev YV and Wallach D: Involvement of MACH, a novel MORT1/FADD-interacting protease, in Fas/APO-1- and TNF receptor-induced cell death. Cell 85(6): 803-815, 1996. PMID: 8681376. DOI: 10.1016/ s0092-8674(00)81265-9

19 Kantari C and Walczak H: Caspase- 8 and bid: caught in the act between death receptors and mitochondria. Biochim Biophys Acta 1813(4): 558-563, 2011. PMID: 21295084. DOI: 10.1016/j.bbamcr.2011.01.026

20 Cai J, Yang J and Jones DP: Mitochondrial control of apoptosis: the role of cytochrome c. Biochim Biophys Acta 1366(1-2): 139-149, 1998. PMID: 9714780. DOI: 10.1016/s0005-2728(98)00109-1

21 Herbst RS: Review of epidermal growth factor receptor biology. Int J Radiat Oncol Biol Phys 59(2 Suppl): 21-26, 2004. PMID: 15142631. DOI: 10.1016/j.ijrobp.2003.11.041

22 Oda K, Matsuoka Y, Funahashi A and Kitano H: A comprehensive pathway map of epidermal growth factor receptor signaling. Mol Syst Biol 1: 2005.0010, 2005. PMID: 16729045. DOI: $10.1038 / \mathrm{msb} 4100014$

23 Liccardi G, Hartley JA and Hochhauser D: EGFR nuclear translocation modulates DNA repair following cisplatin and ionizing radiation treatment. Cancer Res 71(3): 1103-1114, 2011. PMID: 21266349. DOI: 10.1158/0008-5472.CAN-10-2384

24 Sakai A, Kasahara K, Ohmori T, Kimura H, Sone T, Fujimura $\mathrm{M}$ and Nakao S: MET increases the sensitivity of gefitinibresistant cells to $\mathrm{SN}-38$, an active metabolite of irinotecan, by up-regulating the topoisomerase I activity. J Thorac Oncol 7(9): 1337-1344, 2012. PMID: 22722827. DOI: 10.1097/JTO. $0 \mathrm{~b} 013 \mathrm{e} 31825 \mathrm{cca} 4 \mathrm{c}$

25 Thakur M, Shaeib F, Khan SN, Kohan-Ghadr HR, Jeelani R, Aldhaheri SR, Gonik B and Abu-Soud HM: Galactose and its metabolites deteriorate metaphase II mouse oocyte quality and subsequent embryo development by disrupting the spindle structure. Sci Rep 7(1): 231, 2017. PMID: 28331195. DOI: 10.1038/s41598-017-00159-y

26 Yang H, Villani RM, Wang H, Simpson MJ, Roberts MS, Tang $\mathrm{M}$ and Liang $\mathrm{X}$ : The role of cellular reactive oxygen species in cancer chemotherapy. J Exp Clin Cancer Res 37(1): 266, 2018. PMID: 30382874. DOI: 10.1186/s13046-018-0909-x

27 Perillo B, Di Donato M, Pezone A, Di Zazzo E, Giovannelli P, Galasso G, Castoria G and Migliaccio A: ROS in cancer therapy: the bright side of the moon. Exp Mol Med 52(2): 192-203, 2020. PMID: 32060354. DOI: 10.1038/s12276-020-0384-2

28 Zaidieh T, Smith JR, Ball KE and An Q: ROS as a novel indicator to predict anticancer drug efficacy. BMC Cancer 19(1): 1224, 2019. PMID: 31842863. DOI: 10.1186/s12885-019-6438-y

29 Davalli P, Marverti G, Lauriola A and D'Arca D: Targeting oxidatively induced DNA damage response in cancer: Opportunities for novel cancer therapies. Oxid Med Cell Longev 2018: 2389523, 2018. PMID: 29770165. DOI: 10.1155/2018/2389523 
30 Maréchal A and Zou L: DNA damage sensing by the ATM and ATR kinases. Cold Spring Harb Perspect Biol 5(9): a012716, 2013. PMID: 24003211. DOI: 10.1101/cshperspect.a012716

31 Kidiyoor GR, Kumar A and Foiani M: ATR-mediated regulation of nuclear and cellular plasticity. DNA Repair (Amst) 44: 143-150, 2016. PMID: 27283761. DOI: 10.1016/j.dnarep.2016.05.020

32 Kulkarni A and Das KC: Differential roles of ATR and ATM in p53, Chk1, and histone H2AX phosphorylation in response to hyperoxia: ATR-dependent ATM activation. Am J Physiol Lung Cell Mol Physiol 294(5): L998-L1006, 2008. PMID: 18344416. DOI: 10.1152/ajplung.00004.2008

33 Leung-Pineda V, Ryan CE and Piwnica-Worms H: Phosphorylation of Chk 1 by ATR is antagonized by a Chk1-regulated protein phosphatase 2A circuit. Mol Cell Biol 26(20): 7529-7538, 2006. PMID: 17015476. DOI: 10.1128/MCB.00447-06

34 Zorov DB, Juhaszova M and Sollott SJ: Mitochondrial reactive oxygen species (ROS) and ROS-induced ROS release. Physiol Rev 94(3): 909-950, 2014. PMID: 24987008. DOI: 10.1152/ physrev.00026.2013

35 Wiley L, Ashok D, Martin-Ruiz C, Talbot DC, Collerton J, Kingston A, Davies K, Chinnery PF, Catt M, Jagger C, Kirkwood $\mathrm{TB}$ and von Zglinicki T: Reactive oxygen species production and mitochondrial dysfunction in white blood cells are not valid biomarkers of ageing in the very old. PLoS One 9(3): e91005, 2014. PMID: 24614678. DOI: 10.1371/journal.pone.0091005

36 Zhou HB and Zhu JR: Paclitaxel induces apoptosis in human gastric carcinoma cells. World J Gastroenterol 9(3): 442-445, 2003. PMID: 12632493. DOI: 10.3748/wjg.v9.i3.442

37 Wei $\mathrm{C}$ and Li X: Verteporfin inhibits cell proliferation and induces apoptosis in different subtypes of breast cancer cell lines without light activation. BMC Cancer 20(1): 1042, 2020. PMID: 33121449. DOI: 10.1186/s12885-020-07555-0

38 Zhang HW, Hu JJ, Fu RQ, Liu X, Zhang YH, Li J, Liu L, Li YN, Deng Q, Luo QS, Ouyang Q and Gao N: Flavonoids inhibit cell proliferation and induce apoptosis and autophagy through downregulation of $\mathrm{PI} 3 \mathrm{~K} \gamma$ mediated PI3K/AKT/mTOR/ p70S6K/ULK signaling pathway in human breast cancer cells. Sci Rep 8(1): 11255, 2018. PMID: 30050147. DOI: 10.1038/s41598-018-29308-7

39 Ashkenazi A: Targeting the extrinsic apoptotic pathway in cancer: lessons learned and future directions. J Clin Invest 125(2): 487-489, 2015. PMID: 25642709. DOI: 10.1172/JCI80420

40 Ricci MS and Zong WX: Chemotherapeutic approaches for targeting cell death pathways. Oncologist 11(4): 342-357, 2006. PMID: 16614230. DOI: 10.1634/theoncologist.11-4-342

41 Fulda S and Debatin KM: Extrinsic versus intrinsic apoptosis pathways in anticancer chemotherapy. Oncogene 25(34): 47984811, 2006. PMID: 16892092. DOI: 10.1038/sj.onc.1209608

42 Elmore S: Apoptosis: a review of programmed cell death. Toxicol Pathol 35(4): 495-516, 2007. PMID: 17562483. DOI: $10.1080 / 01926230701320337$

43 Dasika GK, Lin SC, Zhao S, Sung P, Tomkinson A and Lee EY: DNA damage-induced cell cycle checkpoints and DNA strand break repair in development and tumorigenesis. Oncogene 18(55): 7883-7899, 1999. PMID: 10630641. DOI: 10.1038/ sj.onc. 1203283

44 Pellegata NS, Antoniono RJ, Redpath JL and Stanbridge EJ: DNA damage and p53-mediated cell cycle arrest: a reevaluation. Proc Natl Acad Sci U S A 93(26): 15209-15214, 1996. PMID: 8986789. DOI: $10.1073 /$ pnas.93.26.15209
45 Ferenbach DA and Bonventre JV: The molecular response to renal injury: How does chronic renal damage suppress normal repair processes? In: Kidney development, disease, repair and regeneration. Little MH (eds.). Elsevier, pp. 367-379, 2016.

46 Helt CE, Cliby WA, Keng PC, Bambara RA and O'Reilly MA: Ataxia telangiectasia mutated (ATM) and ATM and Rad3-related protein exhibit selective target specificities in response to different forms of DNA damage. J Biol Chem 280(2): 11861192, 2005. PMID: 15533933. DOI: 10.1074/jbc.M410873200

47 Shirata N, Kudoh A, Daikoku T, Tatsumi Y, Fujita M, Kiyono T, Sugaya $\mathrm{Y}$, Isomura $\mathrm{H}$, Ishizaki $\mathrm{K}$ and Tsurumi T: Activation of ataxia telangiectasia-mutated DNA damage checkpoint signal transduction elicited by herpes simplex virus infection. J Biol Chem 280(34): 30336-30341, 2005. PMID: 15964848. DOI: 10.1074/jbc.M500976200

48 Abraham RT: Cell cycle checkpoint signaling through the ATM and ATR kinases. Genes Dev 15(17): 2177-2196, 2001. PMID: 11544175. DOI: $10.1101 / \mathrm{gad} .914401$

49 Shen $\mathrm{T}$ and Huang S: The role of Cdc25A in the regulation of cell proliferation and apoptosis. Anticancer Agents Med Chem 12(6): 631-639, 2012. PMID: 22263797. DOI: 10.2174/18715201 2800617678

50 Kwon Y, Kim M, Jung HS, Kim Y and Jeoung D: Targeting autophagy for overcoming resistance to anti-EGFR treatments. Cancers (Basel) 11(9): 1374, 2019. PMID: 31527477. DOI: 10.3390/cancers 11091374

51 Rosenkranz AA and Slastnikova TA: Epidermal growth factor receptor: Key to selective intracellular delivery. Biochemistry (Mosc) 85(9): 967-1092, 2020. PMID: 33050847. DOI: $10.1134 / \mathrm{S} 0006297920090011$

52 Treda C, Popeda M, Ksiazkiewicz M, Grzela DP, Walczak MP, Banaszczyk M, Peciak J, Stoczynska-Fidelus E and Rieske P: EGFR activation leads to cell death independent of PI3K/AKT/mTOR in an AD293 cell line. PLoS One 11(5): e0155230, 2016. PMID: 27153109. DOI: 10.1371/journal.pone.0155230

53 Adams JM and Cory S: Bcl-2-regulated apoptosis: mechanism and therapeutic potential. Curr Opin Immunol 19(5): 488-496, 2007. PMID: 17629468. DOI: 10.1016/j.coi.2007.05.004

54 Danial NN: BCL-2 family proteins: critical checkpoints of apoptotic cell death. Clin Cancer Res 13(24): 7254-7263, 2007. PMID: 18094405. DOI: 10.1158/1078-0432.CCR-07-1598

55 Alarifi S, Ali H, Alkahtani S and Alessia MS: Regulation of apoptosis through bcl-2/bax proteins expression and DNA damage by nano-sized gadolinium oxide. Int J Nanomedicine 12: 4541-4551, 2017. PMID: 28684914. DOI: 10.2147/IJN.S139326

56 Kim HE, Du F, Fang M and Wang X: Formation of apoptosome is initiated by cytochrome c-induced dATP hydrolysis and subsequent nucleotide exchange on Apaf-1. Proc Natl Acad Sci USA 102(49): 17545-17550, 2005. PMID: 16251271. DOI: 10.1073/pnas.0507900102

57 Parrish AB, Freel CD and Kornbluth S: Cellular mechanisms controlling caspase activation and function. Cold Spring Harb Perspect Biol 5(6): a008672, 2013. PMID: 23732469. DOI: 10.1101/cshperspect.a008672

58 Los M, Mozoluk M, Ferrari D, Stepczynska A, Stroh C, Renz A, Herceg Z, Wang ZQ and Schulze-Osthoff K: Activation and caspase-mediated inhibition of PARP: a molecular switch between fibroblast necrosis and apoptosis in death receptor signaling. Mol Biol Cell 13(3): 978-988, 2002. PMID: 11907276. DOI: $10.1091 / \mathrm{mbc} .01-05-0272$ 
59 Schieber M and Chandel NS: ROS function in redox signaling and oxidative stress. Curr Biol 24(10): R453-R462, 2014. PMID: 24845678. DOI: 10.1016/j.cub.2014.03.034

60 Borges HL, Linden R and Wang JY: DNA damage-induced cell death: lessons from the central nervous system. Cell Res 18(1): 17-26, 2008. PMID: 18087290. DOI: 10.1038/cr.2007.110

61 Gagou ME, Zuazua-Villar P and Meuth M: Enhanced H2AX phosphorylation, DNA replication fork arrest, and cell death in the absence of Chk1. Mol Biol Cell 21(5): 739-752, 2010. PMID: 20053681. DOI: 10.1091/mbc.e09-07-0618

62 Bonner WM, Redon CE, Dickey JS, Nakamura AJ, Sedelnikova OA, Solier S and Pommier Y: GammaH2AX and cancer. Nat Rev Cancer 8(12): 957-967, 2008. PMID: 19005492. DOI: $10.1038 / \mathrm{nrc} 2523$

63 Matsuura K, Wakasugi M, Yamashita K and Matsunaga T: Cleavage-mediated activation of Chk1 during apoptosis. J Biol Chem 283(37): 25485-25491, 2008. PMID: 18550533. DOI: 10.1074/jbc.M803111200

64 Myers K, Gagou ME, Zuazua-Villar P, Rodriguez R and Meuth M: ATR and Chk1 suppress a caspase-3-dependent apoptotic response following DNA replication stress. PLoS Genet 5(1): e1000324, 2009. PMID: 19119425. DOI: 10.1371/journal.pgen.1000324

65 Guicciardi ME and Gores GJ: Life and death by death receptors. FASEB J 23(6): 1625-1637, 2009. PMID: 19141537. DOI: 10.1096/fj.08-111005

66 Schneider-Brachert W, Heigl U and Ehrenschwender M: Membrane trafficking of death receptors: implications on signalling. Int J Mol Sci 14(7): 14475-14503, 2013. PMID: 23852022. DOI: 10.3390/ijms140714475

67 Yuan X, Gajan A, Chu Q, Xiong H, Wu K and Wu GS: Developing TRAIL/TRAIL death receptor-based cancer therapies. Cancer Metastasis Rev 37(4): 733-748, 2018. PMID: 29541897. DOI: 10.1007/s10555-018-9728-y

68 Dai X, Zhang J, Arfuso F, Chinnathambi A, Zayed ME, Alharbi SA, Kumar AP, Ahn KS and Sethi G: Targeting TNF-related apoptosis-inducing ligand (TRAIL) receptor by natural products as a potential therapeutic approach for cancer therapy. Exp Biol Med (Maywood) 240(6): 760-773, 2015. PMID: 25854879. DOI: $10.1177 / 1535370215579167$

69 Elrod HA and Sun SY: Modulation of death receptors by cancer therapeutic agents. Cancer Biol Ther 7(2): 163-173, 2008 PMID: 18059181. DOI: 10.4161/cbt.7.2.5335

70 Tummers B and Green DR: Caspase-8: regulating life and death. Immunol Rev 277(1): 76-89, 2017. PMID: 28462525. DOI: 10.1111/imr.12541

71 Beaudouin J, Liesche C, Aschenbrenner S, Hörner M and Eils $\mathrm{R}$ : Caspase- 8 cleaves its substrates from the plasma membrane upon CD95-induced apoptosis. Cell Death Differ 20(4): 599 610, 2013. PMID: 23306557. DOI: 10.1038/cdd.2012.156

72 Huang K, Zhang J, O'Neill KL, Gurumurthy CB, Quadros RM, $\mathrm{Tu} \mathrm{Y}$ and Luo X: Cleavage by caspase 8 and mitochondrial membrane association activate the $\mathrm{BH} 3$-only protein bid during TRAIL-induced apoptosis. J Biol Chem 291(22): 11843-11851, 2016. PMID: 27053107. DOI: 10.1074/jbc.M115.711051
73 Wang Y and Tjandra N: Structural insights of tBid, the caspase-8activated Bid, and its BH3 domain. J Biol Chem 288(50): 3584035851, 2013. PMID: 24158446. DOI: 10.1074/jbc.M113.503680

74 Gogvadze V, Orrenius S and Zhivotovsky B: Multiple pathways of cytochrome $\mathrm{c}$ release from mitochondria in apoptosis. Biochim Biophys Acta 1757(5-6): 639-647, 2006. PMID: 16678785. DOI: 10.1016/j.bbabio.2006.03.016

75 Manic G, Obrist F, Sistigu A and Vitale I: Trial Watch: Targeting ATM-CHK2 and ATR-CHK1 pathways for anticancer therapy. Mol Cell Oncol 2(4): e1012976, 2015. PMID: 27308506. DOI: 10.1080/23723556.2015.1012976

76 Reinhardt HC and Yaffe MB: Kinases that control the cell cycle in response to DNA damage: Chk1, Chk2, and MK2. Curr Opin Cell Biol 21(2): 245-255, 2009. PMID: 19230643. DOI: 10.1016/j.ceb.2009.01.018

77 Wee P and Wang Z: Epidermal growth factor receptor cell proliferation signaling pathways. Cancers (Basel) 9(5): 52, 2017. PMID: 28513565. DOI: 10.3390/cancers 9050052

78 Mendoza MC, Er EE and Blenis J: The Ras-ERK and PI3KmTOR pathways: cross-talk and compensation. Trends Biochem Sci 36(6): 320-328, 2011. PMID: 21531565. DOI: 10.1016/ j.tibs.2011.03.006

$79 \mathrm{Yu}$ JS and Cui W: Proliferation, survival and metabolism: the role of PI3K/AKT/mTOR signalling in pluripotency and cell fate determination. Development 143(17): 3050-3060, 2016. PMID: 27578176. DOI: $10.1242 /$ dev.137075

80 Leung JC and Cassimeris L: Reorganization of paclitaxel-stabilized microtubule arrays at mitotic entry: roles of depolymerizing kinesins and severing proteins. Cancer Biol Ther 20(10): 13371347, 2019. PMID: 31345098. DOI: 10.1080/15384047.2019. 1638678

81 Snyder JP, Nettles JH, Cornett B, Downing KH and Nogales E: The binding conformation of Taxol in beta-tubulin: a model based on electron crystallographic density. Proc Natl Acad Sci USA 98(9): 5312-5316, 2001. PMID: 11309480. DOI: 10.1073/pnas.051309398

82 Gupta ML Jr, Bode CJ, Georg GI and Himes RH: Understanding tubulin-Taxol interactions: mutations that impart Taxol binding to yeast tubulin. Proc Natl Acad Sci USA 100(11): 6394-6397, 2003. PMID: 12740436. DOI: 10.1073/pnas.1131967100

83 Mukhtar E, Adhami VM and Mukhtar H: Targeting microtubules by natural agents for cancer therapy. Mol Cancer Ther 13(2): 275-284, 2014. PMID: 24435445. DOI: 10.1158/1535-7163. MCT-13-0791

84 Blajeski AL, Phan VA, Kottke TJ and Kaufmann SH: G(1) and G(2) cell-cycle arrest following microtubule depolymerization in human breast cancer cells. J Clin Invest 110(1): 91-99, 2002. PMID: 12093892. DOI: 10.1172/JCI13275

Received April 2, 2021

Revised June 10, 2021

Accepted June 16, 2021 